
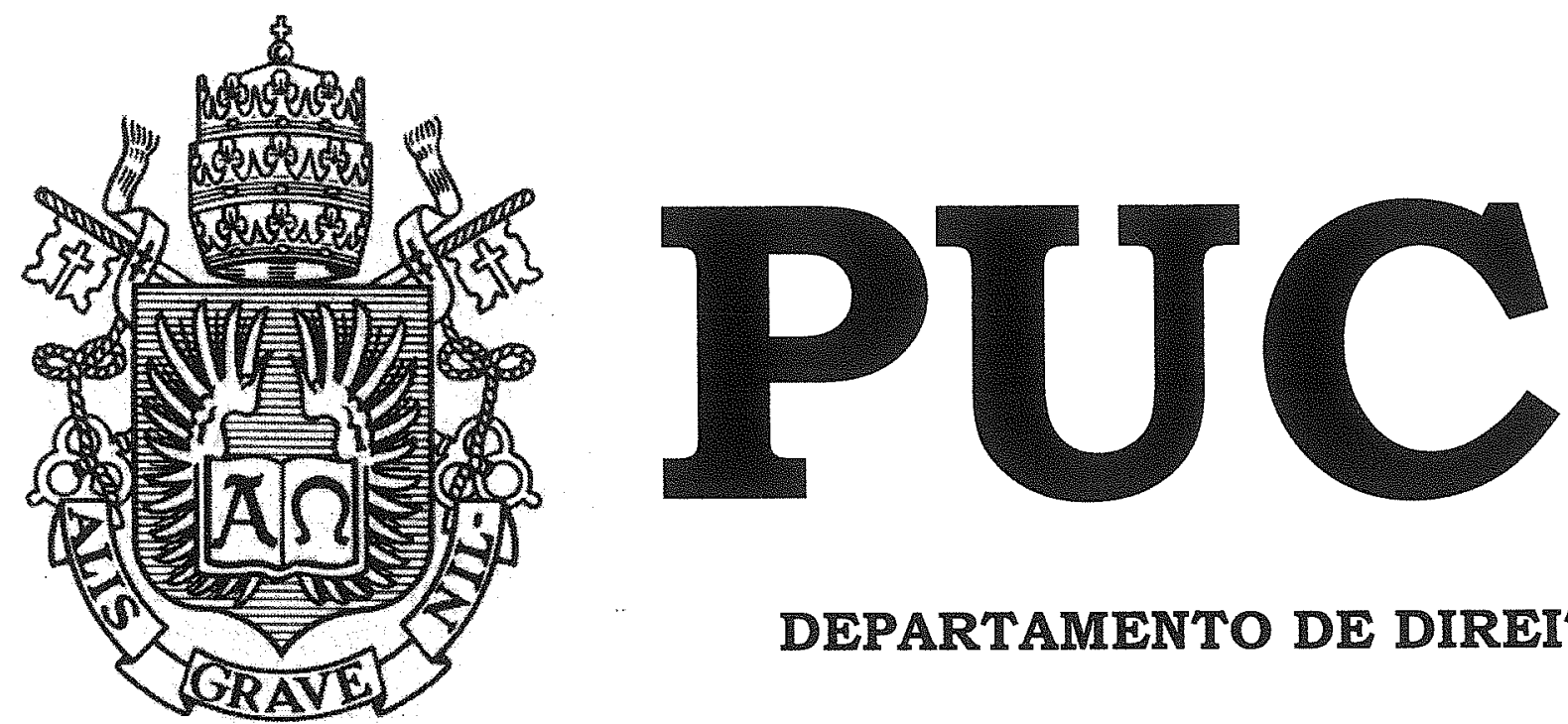

DEPARTAMENTO DE DIREITO

\title{
UMA ANÁlISE PRÁTICA DA OFERTA PÚBLICA DE AQUISIÇÃO DE AÇÕES POR ALIENAÇÃO DE CONTROLE ACIONÁRIO
}

\author{
por \\ LAURA FAILLACE RONCA ANGRISANI
}

ORIENTADOR(A): Norma Jonssen Parente

2015.2

PONTIFÍCIA UNIVERSIDADE CATÓLICA DO RIO DE JANEIRO

RUA MARQUÊS DE SÃO VICENTE, 225 - CEP 22453-900

RIO DE JANEIRO - BRASIL 


\title{
UMA ANÅLISE PRÅTICA DA OFERTA PÚBLICA DE AQUISIÇÃO DE AÇÕES POR ALIENAÇÃO DE CONTROLE ACIONÁRIO
}

\author{
por \\ LAURA FAILLACE RONCA ANGRISANI
}

Monografia apresentada ao Departamento de Direito da Pontificia Universidade Católica do Rio de Janeiro (PUC-Rio) para a obtenção do Título de Bacharel em Direito.

Orientador(a): Norma Jonssen Parente 


\section{Dedicatória}

Dedico o presente trabalho aos meus pais, Patricia e Marco Antônio, meus exemplos de força, amor, perseverança e dedicação. À minha avó Helena, que, com muito carinho e, mesmo de longe, me ensinou que o sucesso e reconhecimento são conquistados através de muito esforço e persistência, valores confiados na simplicidade dos nossos desejos. 


\section{Resumo}

Este trabalho visa entender quando se dá a obrigatoriedade de realizar uma oferta pública de aquisição de ações por alienação de controle, prevista em nosso ordenamento no artigo 254-A da Lei das Sociedades Anônimas ("OPA a posteriori"), como também seus conceitos e implicações.

Como ponto de partida, analisamos qual o fundamento e interesse protegido por trás da OPA a posteriori, através do capítulo intitulado "Introdução: a ratio por trás da regra da OPA por alienação de controle".

Em seguida, examinamos como a OPA a posteriori originou-se em nosso ordenamento e toda sua evolução histórica: seu surgimento através do artigo 254 em 1976, depois a revogação deste dispositivo em 1997 e a reintrodução do instituto da OPA por alienação de controle através da reforma na Lei das Sociedades Anônimas, promovida pela Lei 10.303 de 2001 .

Discutimos as classificações da OPA a posteriori e a problemática dos destinatários da oferta pública de alienação de controle por meio de entendimentos doutrinários.

Conceituamos o acionista controlador a partir do artigo 116 da Lei das Sociedades Anônimas, investigamos os tipos de controle e a expressão "controle de companhia", que ora significa bloco de controle, ora poder de controle. No mesmo capítulo, explicamos como se dá a aquisição originária e derivada do controle.

Em vista do crescimento no Brasil das companhias com capital pulverizado, realizamos um breve estudo do fenômeno como evento oposto às sociedades que detêm um controlador definido, passando por uma sucinta explicação sobre as poison pills ou pílulas de veneno, medida protetiva, advinda dos Estados Unidos, contra a aquisição hostil do controle de uma companhia com capital disperso no mercado acionário. 
Não obstante, tratamos do papel importante da CVM nas discussões sobre os casos em que há transferência do controle e apresentamos dois dos principais casos a respeito da alienação de controle deliberados pelo Colegiado da CVM.

Por fim, resta-nos esclarecer que não há por objetivo analisar se a lei societária oferece adequada proteção aos acionistas minoritários, tampouco se é justa com os controladores. O propósito deste trabalho é examinar e interpretar o instituto jurídico da oferta pública de aquisição de ações por alienação do controle acionário, que tanto atrai e fascina os admiradores do direito societário.

\section{Palavras-chave:}

OPA por alienação de controle. OPA a posteriori. Tag along. Poder de controle. Acionista controlador. Aquisição de açôes. Prêmio de controle. Ação com direito de voto. Ações ordinárias. Ações preferenciais. 


\section{Sumário}

1. Introdução: a ratio por trás da regra da OPA por alienação de controle

2. Oferta Pública de Aquisição de Ações - OPA: análise e definições .... 12

2.1. Classificações da OPA: obrigatória e voluntária ................................ 12

2.2. A OPA do artigo 254-A da Lei 6.404/76 ....................................... 13

2.2.1. A trajetória do atual artigo 254-A: reintrodução da OPA por alienação de controle com o advento da Lei 10.303/01 .......................... 13

2.2.2. Alienação direta e indireta do controle ......................................... 17

2.2.3. Os destinatários da OPA: detentores de ações com direito

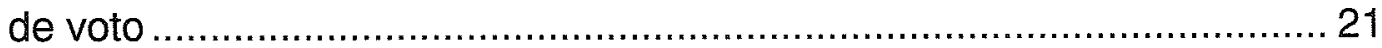

2.2.3.1. A discussão da restrição ilegal do artigo 29 da Instrução

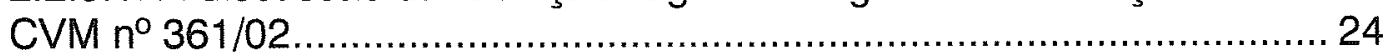

3. Bloco de controle, poder de controle e o acionista controlador............ 28

3.1. O controlador na lei acionária brasileira.......................................... 28

3.1.1. A ambiguidade da expressão "controle da companhia" ................. 31

3.2. Tipos de controle: controle interno e controle externo ....................... 32

3.3. A qualificação jurídica do controle ................................................... 33

3.4. Modalidades de alienação de controle........................................... 35

3.4.1. Aquisição de controle a título originário e a título derivado ............. 37

3.4.2. Acordo de Acionistas .............................................................. 39

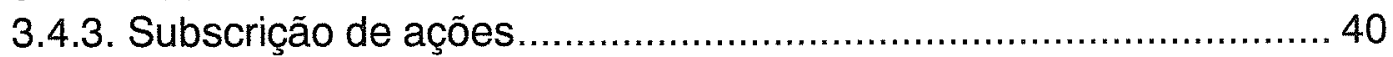

3.5. A pulverização de controle no Brasil .............................................. 41

3.5.1. Poison pill: mecanismo de defesa nas sociedades de capital

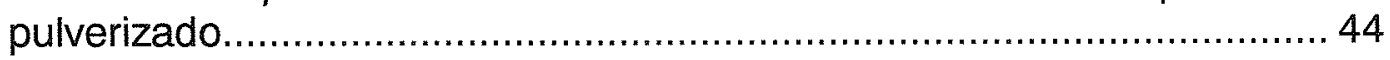

4. A CVM e a OPA por alienação de controle .......................................... 47

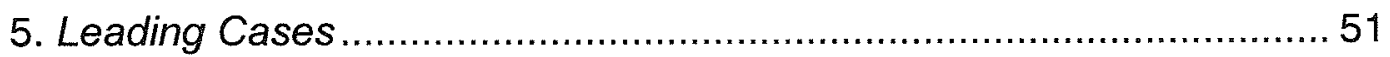

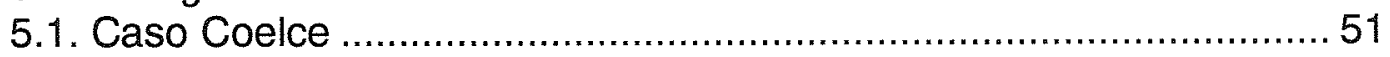

5.1.1. A aquisição originária de controle e a caracterização de um bloco de controle preexistente ............................................................. 53

5.2. Caso Tim Participações ............................................................... 54

5.2.1. Qual a lei aplicável para definir o que é controle e a aplicação do artigo 254-A em alienações de controle minoritário ............................. 57

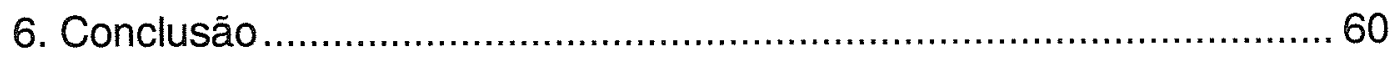

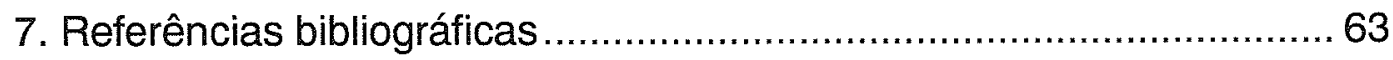


Lista de siglas e abreviações

CVM - Comissão de Valores Mobiliários

LSA - Lei 6.404 de 15 de dezembro de 1976 (Lei das Sociedades Anônimas)

OPA - Oferta pública de aquisição de ações, prevista no artigo 254-A da LSA

CMN - Conselho Monetário Nacional 


\section{Introdução: a ratio por trás da regra da OPA por alienação de controle}

O artigo 254-A da LSA, reintroduzido na Lei 6.404 pela Lei 10.303/2001, dispõe sobre o tema do presente trabalho, qual seja, a obrigação de o adquirente do controle de uma companhia aberta realizar a oferta pública de aquisição de ações dos acionistas minoritários ("OPA a posteriori" ou "OPA obrigatória"). Vale transcrever o caput do dispositivo:

\footnotetext{
"Art. 254-A. A alienação, direta ou indireta, do controle de companhia aberta somente poderá ser contratada sob a condição, suspensiva ou resolutiva, de que o adquirente se obrigue a fazer oferta pública de aquisição das ações com direito a voto de propriedade dos demais acionistas da companhia, de modo a lhes assegurar o preço no mínimo igual a $80 \%$ (oitenta por cento) do valor pago por ação com direito a voto, integrante do bloco de controle" (grifo nosso).
}

Neste capítulo, verificaremos qual o interesse protegido pelo referido dispositivo e o seu fundamento, eis que de imediato pode-se perceber o objetivo de proteger os acionistas minoritários de companhias abertas, em contraposição ao direito do acionista controlador de poder dispor livremente de suas ações. Em seguida, faremos uma análise geral sobre o instituto da Oferta Pública de Aquisição de Ações, dando enfoque à trajetória do atual artigo 254-A que trouxe a socialização parcial do prêmio de controle, inovando em relação ao artigo 254 que foi previsto na redação original da LSA e vigorou de 1976 até 1997.

Conforme postula Paulo Eduardo Penna, a finalidade do artigo 254A vai além da mera proteção ao minoritário ${ }^{1}$. Há também, claramente, a intenção de estimular novas companhias a abrir seu capital social e assim fortalecer o mercado de capitais, uma vez que com direitos positivados e eficientes, investidores estarão mais dispostos a investir em companhias abertas e, com isso, desenvolver o mercado de ações.

Contudo, não há um consenso quanto ao fundamento da proteção ao acionista minoritário. A OPA por alienação de controle pode ser justificada

\footnotetext{
${ }^{1}$ PENNA, Paulo Eduardo. Alienação de controle de companhia aberta. São Paulo: Quartier Latin, 2012. p. 71.
} 
através do argumento de que os minoritários devem ter o direito de se retirar da companhia em decorrência das mudanças na sua estrutura societária, já que o acionista investiu naquela determinada companhia levando em conta quem é o seu controlador. Assim é o entendimento de Nelson Eizirik, Ariadna B. Gaal, Flavia Parente e Marcus de Freitas Henriques:

"É na figura do controlador que os acionistas minoritários depositam sua confiança e, sob este aspecto, trata-se de verdadeira relação intuitu personae. São as características pessoais do controlador que podem motivar a vinculação do investidor/acionista minoritário à companhia. Logo, justifica-se que, na hipótese de mudança de controle, os minoritários tenham o direito de saída, caso não concordem em permanecer associados ao novo acionista controlador" ${ }^{22}$ (grifo nosso).

Assim também já se posicionou o Diretor Eli Loria em seu voto proferido no âmbito do Processo CVM RJ 2007/7230, objeto de deliberação do Colegiado em 11 de julho de 2007:

“O próprio fundamento da OPA, a sua razão de ser, está no resguardo do direito dos acionistas não controladores se retirarem de uma companhia que, uma vez controlada por pessoas diversas da que o fazia antes, já não representa seus interesses".

No entanto, por mais que a alienação de controle possa modificar de forma significativa os negócios da companhia e as bases do investimento dos minoritários, alguns autores, como Paulo Eduardo Penna e Fabio Konder Comparato, entendem que não é este o fundamento primordial da OPA a posteriori.

A LSA obriga que o adquirente do controle realize oferta pública para adquirir as ações pertencentes aos acionistas minoritários titulares de ações com direito a voto, não fazendo qualquer menção aos acionistas titulares de ações preferenciais sem direito a voto ou com voto restrito. A própria Instrução CVM 361/2002 restringiu a oferta aos titulares de ações com "pleno e permanente direito de voto". 4

\footnotetext{
${ }^{2}$ EIZIRIK Nelson; GAAL, Ariadna B.; PARENTE, Flávia; HENRIQUES, Marcus de Freitas. Mercado de capitais - regime jurídico. 2. ed. Rio de Janeiro: Renovar, 2008. p. 588-589.

${ }^{3}$ LORIA, Eli. Processo RJ 2007/7230. CVM. 11 de julho de 2007.

${ }^{4}$ Artigo 29 da instrução CVM n' 361 - "A OPA por alienação de controle de companhia aberta será obrigatória, na forma do art. 254-A da Lei 6.404/76, sempre que houver alienação, de forma direta ou indireta, do controle de companhia aberta, e terá por objeto todas as ações de emissão da
} 
No entanto, os efeitos da troca de controle deveriam ser sentidos pelos acionistas votantes ou não votantes: "assim, se a troca de controle fosse a razão de ser do artigo 254-A, a OPA a posteriori deveria englobar todas as ações detidas pelos minoritários e não apenas as ações votantes". Além disso, a LSA só confere ao minoritário o direito de saída na hipótese específica de alienação onerosa de controle, e a mudança no controle pode ocorrer por outras situações, como transferências das ações do bloco de controle por doação, transmissão causa mortis etc. Esse é mais um forte argumento para quem defende que a OPA a posteriori não tem seu fundamento na troca de controle, do contrário, a LSA deveria ter previsto um direito de saída geral ao acionista minoritário. ${ }^{6}$

Comparato, por sua vez, também não considera a troca de controle o fundamento para a OPA obrigatória do artigo 254-A, uma vez que acredita que o direito de saída do acionista minoritário, ou direito de recesso, já está regulado na LSA pelo seu artigo 137. Para ele, faria mais sentido se a troca de controle fosse hipótese do direito de recesso do que fundamento para a OPA a posteriori. ${ }^{7}$

Ademais, há também quem defenda que a sociedade anônima é uma sociedade de capitais, e não de pessoas, e, portanto, não prevalece o intuitu personae, e sim o intuitu pecuniae, razão pela qual partir da premissa de que o acionista minoritário investe na companhia, levando em conta a figura do controlador, é um argumento ineficaz. ${ }^{8}$

Em contrapartida, encontramos o argumento de que a OPA a posteriori tem como fundamento o tratamento equitativo entre os acionistas e a consequente socialização parcial do prêmio de controle. Este último

companhia às quais seja atribuído o pleno e permanente direito de voto, por disposição legal ou estatutária".

${ }^{5}$ PENNA, op. cit., p. 75.

${ }^{6}$ PENNA, op. cit., p. 75.

${ }^{7}$ COMPARATO, Fabio Konder. O poder de controle na Sociedade Anônima. São Paulo: Ed. Revista dos Tribunais, 1976. p. 261.

${ }^{8}$ PENNA, op. cit., p. 76. 
entendido como "a mais-valia resultante do fato de o objeto do negócio entre o adquirente e o controlador ser o bloco de controle". ${ }^{9}$

O artigo 254, previsto na redação original da LSA e revogado pela Lei $9457 / 97$, previa a socialização total do prêmio de controle e, quando reintroduzido pela Lei $10.303 / 01$, trouxe inovações neste tópico. O novo dispositivo criou a regra de que o preço de compra das ações dos minoritários corresponderá a, no mínimo, $80 \%$ (oitenta por cento) do valor pago pelo adquirente por ação do controle. Assim, o legislador reconheceu que as ações que conferem ao seu titular o poder de controlar a companhia são mais valorizadas no mercado, e, desse modo, na alienação delas, o sobrevalor pago pelas ações que detém o controle deve ser compartilhado entre os acionistas não controladores.

Ademais, o percentual de $80 \%$ (oitenta por cento) exerce um papel importante no retorno da OPA a posteriori, visto que não corresponde a um critério objetivo, e sim à solução encontrada para conciliar os divergentes interesses manifestados ao longo das discussóes da Lei 10.303/2001, posto que existia à época forte corrente que pretendia manter o artigo 254 revogado tal como determinava a Lei 9457/1997. ${ }^{10}$

Registra-se, inclusive, conforme entende boa parte da doutrina, que o fundamento do tratamento igualitário e da socialização do prêmio de controle também explica por que a OPA a posteriori não é obrigatória nas hipóteses de aquisição originária de controle e de alienação não onerosa, sendo certo que (i) na hipótese de aquisição originária, como não há um acionista controlador alienando o controle, não há de se falar em prêmio de controle, e (ii) na hipótese de alienação não onerosa, o tratamento igualitário exigiria que os minoritários tivessem a chance de transferir suas

\footnotetext{
${ }^{9}$ LAMY FILHO et al., 2009, p. 2000.

${ }^{10}$ LGOW, Carla Wainer Chalréo. Oferta pública obrigatória por ocasião de alienação de controle de companhia aberta (artigo 254-A da Lei das S.A.). Revista Semestral de Direito Empresarial, São Paulo, n. 9, p. 6, 2011.
} 
ações para o novo controlador também a título não oneroso, o que não faria sentido. ${ }^{11}$

Enfim, qual seja o fundamento por trás do artigo 254-A da LSA, é importante levar em conta a lição de Bulhões Pedreira que aduz que "a experiência mostra que na interpretação da LSA nunca é demais ressaltar a precariedade da interpretação literal (...)"12, justificando a possibilidade e importância de extrair da norma seu fundamento para uma melhor aplicabilidade e estudo, conforme veremos em toda a exposição do presente trabalho.

\footnotetext{
${ }^{11}$ PENNA, op. cit., p. 78.

${ }^{12}$ PEDREIRA, José Luiz Bulhões. Sistema jurídico da companhia. In: LAMY FILHO, Alfredo; PEDREIRA, José Luiz Bulhôes (Coords.). Direito das companhias. Rio de Janeiro: Forense, 2009. v. 1, p. 180.
} 


\section{Oferta Pública de Aquisição de Ações - OPA: análise e definições}

A OPA a posteriori, como vimos no capítulo anterior, é exigível após a operação de cessão privada de controle e, no entendimento de José Alexandre Tavares Guerreiro, trata-se de instrumento de "proteção patrimonial dos acionistas minoritários, que não sejam parte do negócio translativo do controle", 13 bem como de instrumento limitador do direito de propriedade do acionista controlador, que só poderá vender o controle para um terceiro adquirente caso este último esteja disposto a comprar as ações votantes dos acionistas minoritários.

\subsection{Classificações da OPA: obrigatória e voluntária}

O artigo 254-A da LSA, conforme apresentado no capítulo anterior, trata da obrigatoriedade de realizar uma oferta pública de aquisição de ações na hipótese de alienação de controle da companhia aberta. A obrigatoriedade se dá pelo fato de que todos os acionistas devem ter o direito de vender suas ações ao novo adquirente pelos mesmos termos e condições negociados com o controlador alienante. Esse princípio do tratamento igualitário, conhecido no Brasil por direito de saída conjunta ou tag along, previsto pela LSA, também é regulado pela CVM, na Instrução 361 de 2002, em seu artigo $4^{\circ}$, inciso II, vejamos:

“Art. $4^{\circ} \mathrm{Na}$ realização de uma OPA deverão ser observados os seguintes princípios:

(...)

II - a OPA será realizada de maneira a assegurar tratamento equitativo aos destinatários, permitir-lhes a adequada informação quanto à companhia objeto $\mathrm{e}$ ao ofertante, e dotá-los dos elementos necessários à tomada de uma decisão refletida e independente quanto à aceitação da OPA" (grifo nosso).

\footnotetext{
${ }^{13}$ GUERREIRO, José Alexandre Tavares. Alienação de controle de companhia aberta: o papel das instituições financeiras. Revista de Direito Mercantil, Industrial, Econômico e Financeiro, São Paulo, v. 30, p. 116, 1978.
} 
Entende-se, dessa forma, a criação de uma regra da oferta pública obrigatória de aquisição de ações, conhecida como OPA obrigatória ou OPA a posteriori, detentora de norma específica obrigando a sua realização. Além da OPA por alienação de controle acionário, temos como espécie de OPA obrigatória as hipóteses de cancelamento de registro de companhia aberta e de aumento de participação de acionista controlador, que impeça a liquidez de mercado das ações remanescentes.

As OPAs voluntárias, por um outro lado, realizam-se unicamente por vontade do ofertante de efetuar a aquisição por oferta pública.

Embora essas duas espécies sejam diferentes, independentemente de serem obrigatórias ou voluntárias, as OPAs devem observar alguns procedimentos gerais estabelecidos pela instrução da CVM em questão, no que se refere a princípios gerais, formas de liquidação financeira, intermediação, avaliação, instrumento de OPA, entre outros. No entanto, somente estão sujeitas a registro na CVM as OPAs obrigatórias, em qualquer hipótese, e as voluntárias, apenas quando envolverem permuta por valores mobiliários. ${ }^{14}$

Conclui-se, assim, que, nos casos em que se caracterizar a alienação de controle de companhia aberta, o adquirente tem a obrigação de realizar oferta pública para adquirir as ações pertencentes aos demais acionistas titulares de ações com direito a voto, nos termos do artigo 254-A da LSA.

\subsection{A OPA do artigo 254-A da Lei 6.404176}

\subsubsection{A trajetória do atual artigo 254-A: reintrodução da OPA por alienação de controle com o advento da Lei 10.303/01}

Notava-se, antes da entrada em vigor da atual Lei das S.A., em 1976, a necessidade de estabelecer um regime de igualdade entre todos os acionistas na venda do controle das companhias de capital aberto. $O$

\footnotetext{
${ }^{14} \mathrm{ICVM} \mathrm{n}^{\circ} 361 / 2002$, artigo $2^{\circ}$, parágrafo $1^{\circ}$.
} 
Decreto-lei $2.627 / 70$ então em vigor não atendia mais as vontades dos investidores e da classe empresarial.

Foi assim que, em 1974, o Ministro da Fazenda submeteu ao Presidente da República a Exposição de Motivos do Conselho de Desenvolvimento $\mathrm{n}^{0} 14$, cujos valores foram retirados do II Programa Nacional de Desenvolvimento e visava, como um dos objetivos da reforma societária, o tratamento igualitário dos acionistas na alienação e controle, ${ }^{15}$ da seguinte forma:

"A lei estabelecerá mecanismos que impeçam que cada ação do majoritário possua um valor potencial muito superior ao de cada ação do minoritário; para tanto a lei deve prever um sistema de oferta pública para as transações que envolvam uma parcela substantiva de transferência do capital votante, de modo a assegurar a igualdade de acesso aos minoritários".

Nesse sentido, surgiu a ideia de dividir o prêmio de controle com o acionista minoritário. No entanto, esse não era um entendimento consolidado entre a doutrina. Estudiosos do tema como José Luiz Bulhões Pedreira e Alfredo Lamy Filho defendiam que o direito de receber o prêmio de controle era apenas do acionista controlador, posto que o valor de controle não é um patrimônio da companhia. ${ }^{16}$

Em contrapartida, Carvalhosa defendia o tratamento igualitário entre todos os acionistas, tanto controladores quanto minoritários, sob o argumento de que os acionistas não controladores também haviam contribuído para o capital da companhia. ${ }^{17}$

No entanto, foram José Luiz Bulhões Pedreira e Alfredo Lamy Filho os encarregados de elaborar o anteprojeto da lei das sociedades anônimas e, por este motivo, apresentaram ao Governo Federal um texto que não previa qualquer tratamento igualitário entre os acionistas, muito menos a repartição do prêmio de controle. E foi este o conteúdo do anteprojeto submetido ao Congresso Nacional para aprovação: ${ }^{18}$

\footnotetext{
${ }^{15}$ CARVALHOSA, Modesto. A nova Lei das Sociedades Anônimas. Rio de Janeiro: Paz e Terra, 1976. p. 129.

16 PENNA, op. cit., p. 51.

${ }^{17}$ CARVALHOSA, Modesto. op.cit., p. 119.

${ }^{18}$ PENNA, op. cit., p. 54.
} 
"O Projeto reconhece a realidade do poder do acionista controlador, para atribuirlhe responsabilidades próprias, de que não participam os acionistas minoritários; seria, pois, incoerente que se pretendesse, para efeito de transferência desse poder, negar a sua existência, ou proibir o mercado de lhe atribuir valor econômico".

Não obstante a posição do Governo Federal, durante o trâmite do processo legislativo, apresentaram-se diversas emendas, dentre as quais a $n^{\circ}$ 26, mais conhecida como Emenda Lehmann, do senador Otto Lehmann, que, seguindo a ideologia da Exposição de Motivos do Conselho de Desenvolvimento $\mathrm{n}^{\mathrm{o}} 14$ e contra os autores do projeto ${ }^{19}$, foi aprovada na forma do artigo $254^{20}$.

O projeto, então, converteu-se na Lei 6.404, de 15 de dezembro de 1976 e, a partir de então, com o advento do artigo 254, o adquirente do controle acionário de companhia aberta deveria realizar oferta pública para aquisição das ações dos acionistas minoritários, pelo mesmo preço pago por ação integrante do bloco de controle, consagrando, dessa maneira, o tratamento igualitário entre os controladores e os minoritários na alienação de controle.

Ainda sobre as polêmicas em torno do artigo 254, sete dias após a promulgação da LSA, o CMN criou a Resolução 401, de 22 de dezembro de 1976, regulamentando o direito de venda conjunta, com base no parágrafo $3^{\circ}$ do artigo 254 (a competência regulamentar cabe, hoje, à CVM com base no artigo 254-A, $3^{\circ}$ ). Tal Resolução, no entendimento de alguns especialistas, extrapolou seus poderes regulamentares, estabelecendo, por exemplo, que a oferta pública por alienação de controle era obrigatória apenas às ações com direito de voto, sendo que a LSA não fazia qualquer

\footnotetext{
${ }^{19}$ LAMY FILHO, Alfredo; PEDREIRA, José Luiz Bulhões. A Lei das S.A. (pressupostos, elaboração, aplicação). Rio de Janeiro: Renovar, 1997. p. 268, v. 1.

20 "Art. 254. A alienação do controle da companhia aberta dependerá de prévia autorização da Comissão de Valores Imobiliários. $\$ 1^{\circ}$ A Comissão de Valores Mobiliários deve zelar para que seja assegurado tratamento igualitário aos acionistas minoritários, mediante simultânea oferta pública para aquisição de ações. $\S 2^{\circ}$ Se o número de ações ofertadas, incluindo as dos controladores ou majoritários, ultrapassar o máximo previsto na oferta, será obrigatório o tateio, na forma prevista no instrumento da oferta pública. $\S 3^{\circ}$ Compete ao Conselho Monetário Nacional estabelecer normas a serem observadas na oferta pública relativa à alienação do controle de companhia aberta."
} 
diferenciação. ${ }^{21}$ Tal polêmica foi afastada no próprio caput do artigo 254-A, que apenas abrange as ações com direito a voto.

Eis que, em maio de 1997, ocorreu uma reforma na Lei das Sociedades Anônimas através da Lei $9.457 / 97$ que, responsável pela extinção de diversos direitos dos minoritários, revogou o artigo 254, extinguindo o tag along ou direito de saída conjunta na hipótese de alienação de controle de companhia aberta.

A lei de 1997 teve como justificativa os custos que o adquirente do controle tinha que arcar:

"Dessa maneira, a obrigatoriedade da oferta pública produz o pior dos mundos. Ao mesmo tempo, inibe e dificulta processos de alienação de controle necessários ao saneamento de empresas e produz situação desfavorável aos minoritários, uma vez que o não-saneamento de uma empresa resulta do valor de suas ações, no que se prejudicam, mais que todos os minoritários".

O Projeto Kandir, que resultou na Lei ${ }^{\circ}$ 9.457/1997, se pautava na ideia de que os recursos na aquisição do controle pelo terceiro adquirente, em vez de serem utilizados na capitalização da companhia, estariam sendo usados para adquirir as ações dos minoritários. ${ }^{22}$ Ademais, muito se discutiu à época que o grande objetivo da Lei $n^{\circ} 9.457 / 1997$ na verdade era permitir que a União e o Estado - controladores de diversas companhias abertas-, em meio a um programa de privatizações, não compartilhassem do prêmio de controle com os demais acionistas.

Assim também é o entendimento de outros autores:

"A verdade é que a União e também os Estados que, de modo geral, também trilharam o caminho da privatização foram os grandes beneficiados com a revogação do art. 254 da LSA, recebendo dos adquirentes do controle das empresas estatais a totalidade dos prêmios de controle"23 (grifo nosso).

Após a onda de privatizações, iniciou-se uma forte pressão para que os direitos dos minoritários fossem recuperados. Isso porque a exclusão do artigo $254 \mathrm{e}$, por conseguinte, do direito ao tag along, causou muitos prejuízos aos acionistas minoritários, no entendimento de autores como

\footnotetext{
${ }^{21}$ PENNA, op. cit., p. 58.

${ }^{22}$ EIZIRIK, Nelson. Oferta pública de aquisição na alienação do controle de companhia aberta. In: Temas de Direito Societário. Rio de Janeiro: Renovar, 2005. p. 321.

${ }^{23}$ PENNA, op.cit., p. 62.
} 
Norma Parente e Arnoldo Wald ${ }^{24}$. Além do que a Lei 9.457/97 trouxe um "clima de insegurança entre os investidores". 25

E assim foi editada a Lei 10.303/01 que reintroduziu à LSA o artigo 254-A com uma diferença fundamental: o novo dispositivo estabeleceu a socialização parcial do prêmio de controle, isto é, do preço pago por ação do bloco de controle, $80 \%$ (oitenta por cento) deverão ser oferecidos aos minoritários.

Em 2002, a CVM editou a Instrução no 361 que dispôs sobre a oferta pública de aquisição de ações de companhias abertas, dentre elas, a oferta pública por alienação de controle.

Por fim, vale expor o entendimento majoritário da doutrina de que a reintrodução do artigo 254-A no direito brasileiro reforça a conclusão de que o bloco das ações pertencentes ao controlador possui valor econômico próprio. Nas palavras de Roberta Nioc Prado:

"Partindo da premissa de que o poder de controle possui valor econômico próprio distinto de que o poder de controle possui valor individualmente considerado de cada ação que o integra, que o legislador de 1976 passou expressamente a obrigar a OPA a posterior na alienação privada de controle". ${ }^{26}$

\subsubsection{Alienação direta e indireta do controle}

A alienação do controle de uma companhia brasileira, no ordenamento pátrio, pode se dar de forma direta ou indireta. O próprio artigo 254-A, da LSA, refere-se, em seu caput, à alienação direta ou indireta do controle da companhia.

A alienação do controle direto da companhia ocorre quando o controlador, titular das ações pertencentes ao bloco de controle, transfere-as a um terceiro adquirente que, por sua vez, irá passar a exercer o direito de

\footnotetext{
${ }^{24}$ WALD, Arnaldo. O governo das empresas. Revista de Direito Bancário, do Mercado de Capitais e da Arbitragem, São Paulo, v. 15, p. 68, 2002.

${ }^{25}$ PARENTE, Norma. Principais inovaçôes introduzidas pela lei $\mathrm{n}^{\circ} 10.303$, de 31 de outubro de 2001, à lei de sociedade por ações. In: LOBO, Jorge (Coord.). Reforma da Lei das Sociedades Anônimas. Rio de Janeiro: Forense, 2002. p. 40.

${ }^{26}$ PRADO, Roberta Nioac. Oferta pública de ações obrigatória nas S.A.: "tag along". São Paulo: Quartier Latin, 2005. p. 43.
} 
controle, determinando as linhas de atuação da companhia e elegendo seus administradores. $^{27}$

Em contraposição, encontramos o fenômeno do controle indireto, próprio de um grupo de sociedades. Nas palavras de Carlos Augusto da Silveira Lobo:

"A estrutura dos grupos de sociedade pode desdobrar-se em um ou mais degraus. A sociedade de comando do grupo pode controlar diretamente as sociedades controladas, ou indiretamente, através de outras sociedades controladas. De se observar que, havendo grupo de sociedades, há sempre controle indireto, pois o acionista controlador da sociedade de comando controla indiretamente as sociedades controladas diretamente ou indiretamente pela sociedade de comando". ${ }^{28}$

A própria LSA, em seu artigo 243 , parágrafo $2^{\circ}$, reconhece a existência de um controle indireto e se utiliza de conceitos como sociedade controlada e controladora, in verbis:

"Art. 243. O relatório anual da administração deve relacionar os investimentos da companhia em sociedades coligadas e controladas e mencionar as modificaçóes ocorridas durante o exercício.

(...)

$\S 2^{\circ}$ Considera-se controlada a sociedade na qual a controladora, diretamente ou através de outras controladas, é titular de direitos de sócio que the assegurem, de modo permanente, preponderância nas deliberaçóes sociais e o poder de eleger a maioria dos administradores" (grifo nosso).

Tais considerações são relevantes para que se perceba que a alienação de controle também ocorre indiretamente, como se pode observar no seguinte exemplo: a holding $\mathrm{A}$, controladora da sociedade $\mathrm{B}$ que, por sua vez, controla a sociedade $\mathrm{C}$, tem o seu controle direto alienado. Desse modo, por si só, B e C têm os seus controles indiretos transferidos. Assim, na vigência do artigo 254-A da LSA, a OPA a posteriori é obrigatória também quando a alienação do controle se dá de forma indireta.

Confira-se, nesse sentindo, o entendimento da CVM no julgamento do processo $\mathrm{RJ} \mathrm{n}^{\circ}$ 2006/7658, em que fica claro que, ocorrendo alienação

\footnotetext{
${ }^{27}$ PENNA, op. cit., p. 125.

${ }^{28}$ LOBO, Carlos Augusto da Silveira. Alienação de controle de companhia aberta. In: LAMY FILHO, Alfredo; PEDREIRA, José Luiz Bulhões (Coords.). Direito das companhias. Rio de Janeiro: Forense, 2009. v. 2, p. 2.016.
} 
do controle direto do controlador indireto, o adquirente não poderá se eximir de realizar a OPA a posteriori:

"Cumpre evidenciar que os casos de não-incidencia do preceito legal, na modalidade de OPA em tela, só têm sido deferidos por esta Autarquia nas hipóteses em que os demais acionistas titulares de ações com direito a voto declaram expressamente que dispensam a realizacão de oferta pública de que trata o art. 254-A da Lei 6404/76 ou, ainda, quando se tratar de uma reestruturacão societária, em que os antigos controladores permanecam como tais, ainda que indiretamente". ${ }^{29}$

Indaga-se, portanto, se na hipótese de uma terceira companhia adquirir o controle da holding também deve-se realizar uma oferta pública para adquirir não só as ações dos minoritários da controladora (holding) quanto das ações dos acionistas minoritários da companhia aberta controlada. No entender de um número significativo de autores, a alienação indireta a que se refere o artigo 254-A é pautada apenas na premissa de evitar desvios e fraudes, não estando o adquirente do controle da holding obrigado a pagar novamente o ágio a outros acionistas de companhias abertas controladas. $^{30}$

Em contraste, como já debatido no primeiro capítulo do presente trabalho, o artigo 254-A tem como fundamento o tratamento equitativo entre os acionistas e a socialização parcial do prêmio do controle. Logo, ao adquirir o controle direto de uma holding, o adquirente está pagando tanto um ágio pelo seu controle quanto um ágio pelo controle indireto das demais companhias controladas. Como observa Paulo Eduardo Penna, "da mesma forma que os minoritários da holding - se organizada sob a forma de companhia aberta - têm o direito, por lei, de participar, parcialmente, do prêmio de controle, os minoritários das companhias controladas também o têm". 31

\footnotetext{
29 Íntegra da disponível ecisão $<\mathrm{http} / / /$ www.cvm.gov.br/export/sites/cvm/decisoes/anexos/0003/5464-0.pdf $>$. Acesso em: 21 out. 2015.

30 WALD, Alexandre de Mendonça; MORAES, Luiza Rangel. Transferência de controle da companhia aberta. Algumas questões para estudo e reflexão. Revista de Direito Bancário e do Mercado de Capitais, São Paulo, n. 38, p. 36, 2007.

${ }^{31}$ PENNA, op. cit., p. 130-131.
} 
No mais, tem-se discutido sobre a necessidade de realização de OPA a posteriori no caso da controladora indireta ser uma companhia estrangeira e a companhia aberta controlada uma companhia constituída de acordo com as leis brasileiras.

No caso objeto do Processo CVM RJ 2009/1956, o professor Marcelo Trindade, em seu parecer, afirma que a lei responsável por verificar se ocorreu ou não a alienação de controle é aquela que regulou a constituição da sociedade, no evento em questão, a lei brasileira. $\mathrm{O}$ processo em referência será tratado com maiores detalhes no item 5.2. supra, no entanto, para fins de exemplificar o juízo da CVM sobre o assunto, segue posição adotada para a questão:

“(...) o art. 11 da Lei de Introdução ao Código Civil (Decreto-Lei no 4.657/1942 " LICC") estabelece, como regra geral, que as sociedades são regidas pelas leis sob as quais se constituírem; o controle de uma sociedade integra o conjunto de relações essenciais entre seus sócios. A questão de descobrir quem é o controlador de uma sociedade deve ser regida pela lei que regule a própria sociedade, pois a posicão de acionista controlador integra o status de sócio conferido pela titularidade das acões da sociedade, e transforma o agente em órgão da companhia, no sentido de atribuir-lhe direitos, deveres e responsabilidades" (grifo nosso). ${ }^{32}$

O Caso Tim Participações, elucidado acima, tem como procedente o Caso Arcelor Brasil ${ }^{33}$, no qual o Diretor Wladimir Castelo Branco Castro, com base no artigo 11 da LICC, desenvolveu a teoria de que as sociedades devem obedecer as leis do país em que foram constituídas.

Em resumo, é sempre importante verificar se houve alienação do controle indireto da companhia brasileira, ou seja, se o novo controlador determina as linhas de atuação da empresa e elege seus administradores (conforme definição de acionista controlador do artigo 116, da LSA), e não apenas se ocorreu a alienação do controle direto da sua controladora. As particularidades do conceito de controle e acionista controlador serão analisadas na exposição do próximo capítulo.

\footnotetext{
32 Íntegra da decisão está disponível no site da CVM. Acesso em: 21 out. 2015.

${ }^{33}$ Processo CVM RJ n ${ }^{\circ}$ 2006/6209. Íntegra da decisão está disponível no site da CVM. Acesso em: 21 out. 2015 .
} 


\subsubsection{Os destinatários da OPA: detentores de ações com direito de voto}

Cumpre, neste tópico, investigar quais ações serão objeto da OPA obrigatória; o que o artigo 254-A quis dizer, em seu caput, com "demais acionistas"; e, ainda, a problemática acerca das ações preferenciais com e sem direito de voto.

Incialmente, pode-se afirmar que os destinatários da OPA $a$ posteriori são todos os titulares de ações com direito de voto que não integram o bloco de controle. Isto é, será sempre objeto da OPA obrigatória as ações ordinárias, que, por força do artigo 110 da $\operatorname{LSA}^{34}$, terão sempre direito a voto, não sendo de propriedade do acionista controlador alienante. $^{35}$

Durante a vigência do artigo 254, muitos insistiam no fato de que os acionistas sem direito a voto também deveriam participar da oferta pública, uma vez que, como visto, esse artigo determinava o tratamento igualitário aos acionistas minoritários. Para Carlos Augusto da Silveira Lobo, o caput do atual artigo 254-A desautoriza por completo essa ideia. ${ }^{36}$

Além disso, a Resolução 401/76 do CMN, regulamentando o artigo 254 da LSA, já previa a escolha que o legislador adotaria na atual disposição do artigo: a OPA a posteriori deveria abranger apenas as ações com direito de voto de propriedade dos demais acionistas da companhia.

Para Fabio Konder Comparato, a interpretação dada ao artigo 254 pelo Conselho Monetário Nacional era correta, dado que aqueles que não têm direito a voto não participam das deliberações sociais e, por isso, não podem tomar parte do controle da companhia, vejamos:

\footnotetext{
34 "Art. 110. A cada ação ordinária corresponde 1 (um) voto nas deliberações da assembleia-geral. $\S 1^{\circ} \mathrm{O}$ estatuto pode estabelecer limitação ao número de votos de cada acionista. $\S 2^{\circ}$ É vedado atribuir voto plural a qualquer classe de ações."

35 CARVAlHOSA, Modesto. Comentários à Lei das Sociedades Anônimas. São Paulo: Ed. Saraiva, 2009. v. 4, tomo II, p. 161.

${ }^{36}$ LOBO, Carlos Augusto da Silveira. Alienação do Controle de Companhia aberta. In: LAMY FILHO, Alfredo; PEDREIRA, José Luiz Bulhões (Coords.). Direito das companhias. Rio de Janeiro: Forense, 2009. v. 1, p. 180.
} 
"Ora, minoria e maioria são noções que só fazem senso quando referidas ao direito de voto, a assembleias deliberativas ou colégios eleitorais. A leitura do texto em outro sentido só serve para baralhar as cartas. No sistema da nova lei acionária, por exemplo, as ações preferenciais podem ser emitidas até dois terços do capital social (art. $15, \S 2^{\circ}$ ). Nesta hipótese, quando a lei fala em acionistas minoritários estará, porventura, se referindo aos titulares de açóes preferenciais não votantes? Não vemos, portanto, em estrita lógica, nenhuma infringência, pela Resolução 401, do texto do art. 254 da lei". ${ }^{37}$

Para outros autores, no entanto, a dúvida só veio a ser sanada com a reforma legislativa feita pela Lei $n^{\circ} 10.303 / 01$. Como observa Modesto Carvalhosa:

"Embora houvesse dúvidas, no regime da Lei n. 6.404/76, sobre a participação de acionistas sem direito de voto na oferta pública, com as alterações da Lei $n$. 10.303, de 2001, ficou claro, dados os termos expressos deste art. 254-A, caput, que os destinatários da oferta são todos os titulares de ações com direito de voto". 38

Indaga-se, nesse contexto, o que o legislador quis dizer com a expressão "demais acionistas" contida no caput do artigo 254-A. De acordo com alguns autores, a oferta pública abrange todos os acionistas que não participaram do negócio jurídico que ocasionou a alienação de controle. Logo, "o elemento de exclusão do grupo beneficiário da OPA não é a participação no bloco de controle, mas sim a participação no negócio que dá ensejo à alienação de controle". ${ }^{39}$

Isso posto, mesmo que vários acionistas votantes integrem o grupo de controle, mas, no entanto, não tenham participado da negociação da venda das ações do bloco de controle, eles serão beneficiados pela OPA obrigatória.

Em síntese, a concessão do direito de saída conjunta apenas às ações votantes é uma escolha legislativa. Daí surge a problemática em relação aos acionistas titulares das ações preferenciais sem direito de voto. Norma Parente, por um outro lado, sustenta que os minoritários preferencialistas não deveriam ter sido excluídos da OPA por alienação de controle:

\footnotetext{
${ }^{37}$ COMPARATO, Fábio Konder. O poder de controle na Sociedade Snônima. 2. ed. São Paulo: Revista dos Tribunais, 1977.

38 CARVAlHOSA, Modesto. Comentários à Lei das Sociedades Anônimas. São Paulo: Ed. Saraiva, 2009. v. 4, tomo II, p. 161.

${ }^{39}$ PENNA, op. cit., p. 207.
} 
"É lamentável que esse direito não tenha sido estendido ao acionista preferencial. Em termos patrimoniais, a sua contribuição tem o mesmo valor que a dos demais acionistas. É injusto que o direito de vender em conjunto com o controlador não lhe tenha sido outorgado. Penso que esse direito deveria ter sido partilhado entre minoritários ordinários e preferencialistas". ${ }^{40}$

O artigo 17 da LSA confere vantagens econômicas aos acionistas detentores de ações preferencias que, em troca, abrem mão do direito de votar e participar do controle da companhia. No entanto, com a reforma legislativa que também sofreu este artigo com a lei 10.303/01, o estatuto social da companhia pode conferir, às ações preferenciais sem voto ou com voto restrito, o direito de participarem da OPA por alienação do controle, in verbis:

"Art. 17. As preferências ou vantagens das ações preferenciais podem consistir:

I - em prioridade na distribuição de dividendo, fixo ou mínimo;

II - em prioridade no reembolso do capital, com prêmio ou sem ele; ou

III - na acumulação das preferências e vantagens de que tratam os incisos I e II.

$\S 1^{\circ}$ Independentemente do direito de receber ou não o valor de reembolso do capital com prêmio ou sem ele, as ações preferenciais sem direito de voto ou com restrição ao exercício deste direito, somente serão admitidas à negociação no mercado de valores mobiliários se a elas for atribuída pelo menos uma das seguintes preferências ou vantagens: (Redação dada pela Lei $n^{\circ} 10.303$, de 2001)

(...)

III - direito de serem incluídas na oferta pública de alienação de controle, nas condições previstas no art. 254-A, assegurado o dividendo pelo menos igual ao das ações ordinárias" (grifo nosso).

Nessa situação, a ação preferencial sem voto ou com voto restrito, para os efeitos do artigo 254-A, se equipara a uma ação ordinária. Deve-se ficar atento, no entanto, ao fato de que esse direito não decorre da lei, nem do princípio de tratamento equitativo entre os acionistas, mas sim do próprio estatuto social da companhia. ${ }^{41}$

A problemática em relação aos acionistas preferencialistas não para por aí. Vejamos, a seguir, a discussão entre doutrinadores sobre o entendimento da CVM a respeito das ações preferenciais com direito de voto restrito ou que tenham adquirido direito de voto temporário, nos termos do artigo $111, \$ 1^{\circ}$ da LSA no âmbito da OPA obrigatória.

\footnotetext{
${ }^{40}$ PARENTE, Norma. Principais inovações introduzidas pela Lei $n^{\circ} 10.303$, de 31 de outubro de 2001, à Lei de Sociedade por Ações. In: LOBO, Jorge (Coord.). Reforma da Lei das Sociedades Anônimas. Rio de Janeiro: Forense, 2002. p. 39.

${ }^{41}$ PENNA, op. cit., p. 214.
} 


\subsubsection{A discussão da restrição ilegal do artigo 29 da Instrução CVM $n^{\circ} 361 / 02$}

O artigo 29 da Instrução 361/02 da CVM esclarece que a OPA por alienação de controle terá por objeto "todas as ações de emissão da companhia às quais seja atribuído o pleno e permanente direito de voto, por disposição legal ou estatutária" (grifo nosso). Dessa forma, a CVM excluiu por completo a possibilidade de o acionista preferencialista com direito de voto restrito ou que tenha adquirido este direito de modo temporário a participar da OPA a posteriori.

A LSA não distingue ou restringe, como vimos acima, o objeto da oferta pública obrigatória de alienação de controle ao falar em "ações com direito a voto de propriedade dos demais acionistas".

A CVM, ao determinar "o voto pleno e permanente" exorbitou de sua competência, já que estabeleceu uma restrição sem que a lei objeto de sua regulamentação, no caso, a LSA, também o fizesse. Como observa Modesto Carvalhosa, o artigo 254-A da LSA não faz qualquer referência ao critério de plenitude do direito de voto e, para ele, a restrição feita pela CVM é abusiva e odiosa:

"Isto posto, e na estrita conformidade com o presente art. 254-A, são objeto da oferta todas as ações votantes e não apenas as com 'voto pleno'. Assim também serão objeto da oferta todas as ações preferenciais com voto restrito de que fala o caput do art. 111 da lei societária. Insista-se que este art. 254-A fala em 'ações com direito a voto', e não com 'voto pleno' como abusivamente quer a Comissão de Valores Mobiliários. Assim, para os efeitos deste art. 254-A, também as ações preferenciais com voto restrito (art. 111) serão objeto da oferta pública promovida pelos adquirentes do controle". ${ }^{42}$

Ademais, entende o douto jurista que também agiu a CVM de forma abusiva ao estabelecer ao voto o requisito "permanente". Assim, também excluiu por completo os preferencialistas que adquirem o voto através do artigo $111, \S 1^{\circ}$, isto é, aqueles que recebem o direito de exercer temporariamente a autorização legal de voto se a companhia, pelo prazo

\footnotetext{
${ }^{42}$ CARVAlHoSA, Modesto. Comentários à Lei das Sociedades Anônimas. São Paulo: Saraiva, 2009. v. 4, tomo II, p. 163.
} 
previsto no estatuto e não superior a 3 (três) anos consecutivos, deixar de distribuir dividendos a que tiverem direito. Aqui, tem-se o voto pleno, mas não permanente. ${ }^{43}$

Mesmo entendimento é compartilhado por Fabio Ulhôa Coelho e Nelson Eizirik, dado que, para eles "a lei não estabeleceu qualquer restrição quanto ao caráter pleno ou permanente do direito de voto, não podendo evidentemente a norma regulamentar restringir o alcance da Lei". ${ }^{44}$

Os defensores da corrente de que a restrição aos destinatários da oferta pública é ilegal sustentam que tal restrição fere diretamente os princípios constitucionais presentes no artigo 37 da Constituição da República, principalmente o da legalidade e moralidade, concluindo, portanto, ser o referido artigo inconstitucional.

Corrente oposta advogada da tese de que a interpretação dada pela CVM foi correta, posto que a ratio da OPA obrigatória, conforme visto no primeiro capítulo do presente trabalho, baseia-se no princípio do tratamento equitativo entre os acionistas titulares de ações da mesma espécie e na consequente repartição do prêmio de controle.

Os acionistas com direito ao voto restrito influenciam sobre as decisões sociais de maneira limitada, já que participam nas assembleias para aprovarem alterações estatutárias específicas.

No mais, a lei societária, em seu artigo $17, \S 1^{\circ}$ inclui, entre direitos que podem ser outorgados aos preferencialistas, o de participar da OPA por alienação de controle. Logo, o legislador incluiu esse direito ao preferencialista com voto restrito, pois o artigo 254-A não o fez. Portanto, apenas por força estatutária, pode o preferencialista participar da OPA obrigatória. ${ }^{45}$

\footnotetext{
${ }^{43}$ CARVAlHoSA, Modesto. Comentários à Lei das Sociedades Anônimas. São Paulo: Saraiva, 2009. v. 4, tomo II, p. 164.

${ }^{44}$ EIZIRIK, Nelson. Oferta pública de aquisição na Alienação do Controle de Companhia Aberta. In: SADDI, Jairo (Org.). Fusões e aquisições: aspectos jurídicos e econômicos. São Paulo: IOB, 2002. p. 246.

${ }^{45}$ PENNA, op. cit., p. 216.
} 
Nessa conjuntura, importante evidenciar esta ressalva: as companhias listadas no Nível 2 da Bovespa são abraçadas pelo direito à OPA por alienação de controle. É que o novo regulamento de segmento especial de listagem do mercado de ações criado pela BM\&BOVESPA, em vigor desde 2011, prevê que tanto ações ordinárias quanto preferenciais das companhias listadas no Nível 2 têm garantido a OPA a posteriori por $100 \%$ do preço pago por ação integrante do bloco de controle. ${ }^{46}$

$\mathrm{Na}$ sequência, ao instituir o requisito de permanência de voto, a CVM entendeu que como o artigo $111, \S 1^{\circ}$ da LSA, atribui aos acionistas titulares de ações preferenciais o direito de voto até que os dividendos sejam pagos, trata-se de um direito transitório, diferentemente do direito de voto atribuído às ações ordinárias, que seria permanente.

Os autores com pensamento semelhante aduzem que a melhor interpretação é a de que o artigo 254-A só abrange as ações com direito ao voto permanente e pleno, apesar de não fazer essa determinação de forma expressa, e acrescentam que o conceito de permanente é atributo do acionista controlador:

"Não se pode igualar, na alienação de controle, as ações com direito de voto permanente àquelas que tenham adquirido direito de voto temporário, por forca do $\$ 1^{\circ}$ do art. 111 da LSA. O fundamento do art. 254-A é conferir tratamento equitativo às ações que estejam na mesma situação. $O$ art. 116 da LSA define 0 acionista controlador como aquele titular de direitos de voto que the assegurem, de modo permanente, a maioria dos votos nas assembleias gerais e o poder de eleger a maioria dos administradores. O exercício do controle requer, portanto, a permanência da preponderância nas assembleias. As ações com direito de voto permanente, portanto, guardam em si o potencial de integrarem o bloco de controle; já as ações com direito de voto transitório, por sua vez, nunca poderão alcançar tal posição" ${ }^{\text {"47 }}$ (grifo nosso).

\footnotetext{
${ }^{46}$ Lançado no ano 2000, o Novo Mercado estabeleceu desde sua criação um padrão de governança corporativa altamente diferenciado. A partir da primeira listagem, em 2002, ele se tornou o padrão de transparência e governança exigido pelos investidores para as novas aberturas de capital. Na última década, o Novo Mercado firmou-se como uma seção destinada à negociação de ações de empresas que adotam, voluntariamente, práticas de governança corporativa adicionais às que são exigidas pela legislação brasileira. A listagem nesse segmento especial implica adoção de um conjunto de regras societárias que ampliam os direitos dos acionistas, além da adoção de uma política de divulgação de informações mais transparente e abrangente. Disponível em: $<$ http://www.bmfbovespa.com.br/pt-br/servicos/solucoes-para-empresas/segmentos-delistagem/novo-mercado.aspx?idioma=pt-br>. Acesso em: 28 out. 2015.

${ }^{47}$ PENNA, op. cit., p. 219-220.
} 
No mesmo sentido, Carlos Augusto Silveira Lobo argumenta que não se pode admitir tratamento idêntico aos titulares de ações com direito de voto restrito ou temporário aos das ações com direito de voto pleno e permanente para fins de aplicação do artigo 254-A, LSA. ${ }^{48}$

Ainda, vale afirmar que o artigo 254-A, da LSA, deve ser interpretado restritivamente sob a pena de se contrariar a real intenção do legislador. Nas palavras de Frederico Augusto Monte Simionato, "em nenhuma hipótese o legislador fez referência às ações preferenciais com voto restrito. Interpretar extensivamente tal matéria seria conferir amplitude maior que aquela que o legislador quis realmente disciplinar, fugindo, por completo, da interpretação sistemática do texto normativo acionário". 49

Em síntese, esta é uma discussão antiga que, como visto, vem desde a vigência do antigo artigo 254 que não estabelecia quais ações deveriam ser incluídas na OPA por alienação de controle.

${ }^{48}$ LOBO, Carlos Augusto da Silveira. Alienação do Controle de Companhia Aberta. In: LAMY FILHO, Alfredo; PEDREIRA, José Luiz Bulhões (Coords.). Direito das companhias. Rio de Janeiro: Forense, 2009. v. 1, p. 2.020.

${ }^{49}$ SIMIONATO, Frederico Augusto Monte. Considerações sobre tag along e Direito Societário brasileiro. Revista de Direito Mercantil, Industrial, Econômico e Financeiro, v. 153/154, p.31, 2010. 


\section{Bloco de controle, poder de controle e o acionista controlador}

\subsection{O controlador na lei acionária brasileira}

O controlador é aquele que detém o poder de comandar uma sociedade, escolhendo os seus administradores e definindo as linhas básicas de sua atuação. ${ }^{50}$

A lei societária adota a lógica de que o controle é ligado ao mecanismo do funcionamento interno da sociedade, o que significa decorrer da titularidade das ações com direito de voto e da possibilidade de eleição da maioria dos membros do conselho de administração ${ }^{51}$. Nos termos do artigo 116 da LSA:

"Art. 116. Entende-se por acionista controlador a pessoa, natural ou jurídica, ou o grupo de pessoas vinculadas por acordo de voto, ou sob controle comum, que: a) é titular de direitos de sócio que lhe assegurem, de modo permanente, a maioria dos votos nas deliberações da assembléia-geral e o poder de eleger a maioria dos administradores da companhia; $\mathrm{e}$

b) usa efetivamente seu poder para dirigir as atividades sociais e orientar o funcionamento dos órgãos da companhia.

Parágrafo único. O acionista controlador deve usar o poder com o fim de fazer a companhia realizar o seu objeto e cumprir sua função social, e tem deveres e responsabilidades para com os demais acionistas da empresa, os que nela trabalham e para com a comunidade em que atua, cujos direitos e interesses deve lealmente respeitar e atender" (grifo nosso).

Observa-se que a lei societária exige que aquele que tem a maioria nas assembleias se utilize dessa maioria para controlar a sociedade. Temos assim que o aludido artigo apresenta um forte requisito de que é preciso fazer o uso efetivo do poder para dirigir as atividades sociais. ${ }^{52}$

\footnotetext{
${ }^{50}$ BORBA, José Edwaldo Tavares Borba. Direito Societário. 11. ed. São Paulo: Renovar: 2008. p. 346.

${ }^{51}$ DE MELLO FRANCO, Vera Helena. Considerações sobre as Ofertas Públicas para Aquisição de Ações (OPAs) - estado atual da questão. Revista de Direito Mercantil, Industrial, Econômico e Financeiro, Săo Paulo, v. 144, p. 26, 2006.

52 COMPARATO, Fabio Konder; FILHO, Calixto Salomão. O poder de controle na Sociedade Anônima. 6. ed. Rio de Janeiro: Forense: 2014. p. 58.
} 
Em pensamento semelhante, Nelson Eizirik argumenta que "a lei das S.A. reconhece a existência do poder de controle acionário nas sociedades anônimas, definindo-o não em função da titularidade da maioria do capital votante, mas essencialmente em virtude do efetivo exercício da direção das atividades sociais". 53

Note-se, ainda, que o requisito da permanência é atributo das ações de controle. Como observa Fabio Ulhôa Coelho, é um pressuposto relevante, uma vez que o acionista não precisa ser titular de mais da metade do capital com direito a voto para ser considerado acionista controlador:

"O Banco Central, em 1976, estabeleceu que se considera permanente a manifestação do poder de controle se o acionista titulariza ações que lhe asseguram a maioria absoluta de votos ou, quando inexistente alguém nessa situação, se ele obteve maioria, nas três ultimas assembleias gerais. $O$ objeto do preceito regular era a alienação do poder de controle das companhias abertas, a que se deveria proceder, por força do art. 254 da LSA, mediante oferta pública de aquisição de ações, com previa autorização da CVM, para assegurar tratamento paritário aos demais acionistas. Em 1997, com a revogação do referido dispositivo da lei acionaria, é evidente que a norma infralegal, que o disciplina, perde eficácia. O critério, contudo, continua pertinente" ${ }^{94}$ (grifo nosso).

O conceito de acionista controlador do artigo 116 da lei societária foi espelhado no artigo $243, \S 2^{\mathrm{o}^{55}}$, do mesmo diploma legal, o qual considera como controlada a sociedade na qual a controladora, direta ou indiretamente, é titular de direitos de sócio que lhe assegurem, de modo permanente, preponderância nas deliberações sociais e o poder de eleger a maioria dos administradores.

\footnotetext{
${ }^{53}$ EIZIRIK, Nelson. A Lei das S.A. comentada. São Paulo: Quartier Latin, 2011. v. 1, p. 665. ${ }^{54}$ COELHO, Fábio Ulhôa. Curso de Direito Comercial. São Paulo: Saraiva: 2002. v. 2, p. $279-$ 280.

55 "Art. 243. O relatório anual da administração deve relacionar os investimentos da companhia em sociedades coligadas e controladas e mencionar as modificações ocorridas durante o exercício. $\$ 1^{\circ}$ São coligadas as sociedades nas quais a investidora tenha influência significativa. $\$ 2^{\circ}$ Considerase controlada a sociedade na qual a controladora, diretamente ou através de outras controladas, é titular de direitos de sócio que lhe assegurem, de modo permanente, preponderância nas deliberaçóes sociais e o poder de eleger a maioria dos administradores. $\$ 3^{\circ} \mathrm{A}$ companhia aberta divulgará as informações adicionais, sobre coligadas e controladas, que forem exigidas pela Comissão de Valores Mobiliários. $\S^{\circ}$ Considera-se que há influência significativa quando a investidora detém ou exerce o poder de participar nas decisões das políticas financeira ou operacional da investida, sem controlá-la. $\S 5^{\circ}$ E presumida influência significativa quando a investidora for titular de $20 \%$ (vinte por cento) ou mais do capital votante da investida, sem controlá-la" (grifo nosso).
} 
À luz dessas considerações, Modesto Carvalhosa e Nelson Eizirik acreditam que "a figura do acionista controlador está definida, muito clara e precisamente, nos arts. 116 e 243 da Lei das S/A, com extensa sedimentação jurisprudencial e doutrinária, não podendo qualquer agência reguladora, sob pena de ferir o princípio da legalidade, estabelecer conceito de controle ao arrepio da lei de regência, que é a Lei n. 6.404/76".56

A ideia de que um acionista, ou grupo de acionistas, detendo apenas uma parte das açôes da companhia, consegue comandar as atividades sociais e deter o controle se origina da pesquisa feita por Adolf A. Berle e Gardiner C. Means em 1932. A pesquisa que deu origem ao livro "A Moderna Sociedade Anônima e a Propriedade Privada" (The Modern Corporation and Private Property) se fez por grandiosa, pois tratou de identificar dentro de uma sociedade anônima a dissociação entre a propriedade da riqueza produtiva, ou seja, os bens de produção, e o seu controle. $^{57}$

Do estudo norte-americano da separação entre poder de controle e propriedade acionária, e também das lições de Comparato no direito brasileiro, pode-se identificar o surgimento das seguintes modalidades de poder de controle na sociedade anônima: totalitário, majoritário e minoritário.

Os mencionados tipos de controle se baseiam nas formas pelas quais o controle é exercido dentro de uma companhia e têm como fundamento a titularidade das ações votantes da companhia.

Comparato, nesse sentido, aduz que o legislador apenas emprega o termo acionista controlador, de modo que, na interpretação do artigo 116 da lei acionária, é evidente que o requisito de permanência só é aplicável ao controle majoritário, enquanto o uso efetivo do poder é exigido para os casos de controle minoritário uma vez que no controle majoritário o

\footnotetext{
${ }^{56}$ CARVALHOSA, Modesto; EIZIRIK, Nelson. A nova Lei das S.A. Saraiva: 2002. p. 394.

${ }^{57}$ COELHO, Fábio Ulhôa, op. cit., p. 277.
} 
acionista tem seu status de controlador garantido e, portanto, é irrelevante o uso efetivo do poder. ${ }^{58}$

\subsubsection{A ambiguidade da expressão "controle da companhia"}

Segundo postulam José Luiz Bulhões Pedreira e Alfredo Lamy Filho, a expressão controle de companhia não tem um conceito definido no direito societário brasileiro, podendo ora significar bloco de controle, ora poder de controle. ${ }^{59}$

Poder de controle significa "a capacidade que tem um agente de produzir um resultado, impondo a sua vontade perante outro agente, sem que haja, contudo, relação de subordinação" ${ }^{960}$. Assim, depreende-se que exerce o poder de controle, dentro de uma sociedade anônima, aquele que consegue fazer sua vontade prevalecer nas deliberações sociais. O poder de controle, desse modo, se manifesta nas assembleias gerais, por meio do voto. Cada ação proporciona ao acionista o poder jurídico de um voto. Sob tal perspectiva, o poder de controle possui natureza fática, já que não integra o patrimônio daquele que o exerce.

Em sentido oposto, o conjunto das ações detidas pelo acionista controlador constitui o bloco de controle. O bloco de controle integra o patrimônio do acionista e, somente, irá se conservar enquanto fizer parte do patrimônio da mesma pessoa ou mesmo grupo de pessoas vinculado por acordo de acionistas. Por conseguinte, do bloco de controle nasce o poder de controle.

Posto isso, os conceitos de bloco de controle e poder de controle não se confundem apesar da LSA se referir a ambos como controle. $\mathrm{O}$ acionista que quer transferir para um terceiro o poder de controle deverá transferir o

\footnotetext{
${ }^{58}$ COMPARATO, Fabio Konder; FILHO, Calixto Salomão. O poder de controle na Sociedade Anônima. 6. ed. Rio de Janeiro: Forense: 2014. p. 58-59.

${ }^{59}$ PEDREIRA, José Luiz Bulhões; LAMY FILHO, Alfredo. Estrutura da companhia. In: LAMY FILHO, Alfredo; PEDREIRA, José Luiz Bulhões (Coords.). Direito das companhias. Rio de Janeiro: Forense, 2009. v. 1, p. 823.

${ }^{60}$ PENNA, 2012, p. 22-23.
} 
bloco de controle, ou seja, as ações que, em conjunto, formam o bloco de controle. Em síntese, a transferência das ações do bloco de controle implica perda do poder de controle. Nesse contexto, Paulo Eduardo Penna argumenta que "a aquisição, transferência e perda do poder de controle não constituem, por si só, negócios jurídicos, mas acontecimentos resultantes de negócios jurídicos. A aquisição, transferência e perda do bloco de controle, por outro lado, são negócios jurídicos, consubstanciados na aquisição, transferência ou perda da propriedade de cada uma das ações que, agrupadas, formam o bloco de controle". 61

\subsection{Tipos de controle: controle interno e controle externo}

Conforme exposto anteriormente, através da assimilação operada pelos norte-americanos Berle e Means, o poder de controle de uma sociedade se revela de diversas formas.

O controle totalitário se dá com a concentração de quase todas as ações com direito de voto na propriedade de uma única pessoa. Aqui, não há qualquer dissociação entre propriedade e controle. O majoritário, por sua vez, consegue prevalecer a sua vontade nas assembleias gerais da companhia porque é proprietário de mais da metade das ações com direito de voto. ${ }^{62}$

Existe também a possibilidade do acionista, mesmo possuindo menos da metade das ações com direito de voto, dirigir os negócios sociais. A esse controle dá-se o nome de minoritário.

O ponto em comum entre o controle totalitário, majoritário e minoritário é que o proprietário de qualquer um desses controles atua no interior da própria sociedade. "Sua legitimidade e intensidade dependeriam,

\footnotetext{
${ }^{61}$ PENNA, op. cit., p. 26.

${ }^{62}$ PENNA, op. cit., p. 23-24.
} 
em última análise, do número de ações ou votos de que se é titular, proporcionalmente à totalidade dos sufrágios possiveis. $" 63$

A doutrina ainda aponta a existência do controle externo e do controle gerencial. Este último, Diante da extrema pulverização do capital da companhia, será detido pelos administradores que irão se perpetuar no poder, por meio de procurações outorgadas pelos próprios acionistas para representá-los nas assembleias gerais. O controle gerencial é bem comum nos Estados Unidos, porém no Brasil essa forma de controle ainda não se configura. $^{64}$

O controle externo caberia, por fim, a entidades estranhas à estrutura da sociedade como, por exemplo, grandes credores, os quais teriam o poder de controlar a sociedade por meio de cláusulas contratuais. Nas palavras de José Edwaldo Tavares Borba: "o chamado controle externo não é propriamente uma forma de controle, mas sim um processo de influenciação sobre o controle" ${ }^{65}$

\subsection{A qualificação jurídica do controle}

Como é possível observar, o conceito de controle tem sido bastante explorado, bem como referência em todas as regulamentações que vieram normatizar o instituto da alienação de controle.

Desde a vigência do artigo 254, na hoje revogada Resolução 401/76 do $\mathrm{CMN}^{66}$, quanto na atual instrução $361 / 02$ da CVM, o conceito e a qualificação jurídica do controle dizem respeito à realidade social. Mas como defini-lo?

\footnotetext{
${ }^{63}$ COMPARATO, Fabio Konder; FILHO, Calixto Salomão. O poder de controle na Sociedade Anônima. 6. ed. Rio de Janeiro: Forense, 2014. p. 43.

${ }^{64}$ BORBA, José Edwaldo Tavares. Direito Societário. 11. ed. São Paulo: Renovar, 2008. p. 347.

${ }^{65}$ BORBA, José Edwaldo Tavares, op. cit.

66 "Item II: Entende-se por alienaç̆o do controle de companhia aberta, para efeito do disposto no art. 254, da Lei no 6.404, de 15 de dezembro de 1976, e desta Resolucão, o negócio pelo qual o acionista controlador (art. 116 da Lei no 6.404), pessoa física ou jurídica, transfere o poder de controle da companhia mediante venda ou permuta do conjunto das acôes de sua propriedade que lhe assegura, de modo permanente, a maioria dos votos nas deliberacões da Assembléia Geral e o poder de eleger a maioria dos administradores da companhia."
} 
Fabio Konder Comparato, ao analisar o tema, alega que desde a Revolução Industrial, percebe-se que, nas sociedades anônimas, enquanto o investimento acionário sofria uma tendência centrífuga, o núcleo do poder, diferentemente, sofria tendência inversa. ${ }^{67}$

Diante da tentativa de classificarmos o controle, retornemos ao estudo de Berle e Means, que, se utilizando da teoria clássica da concepção da pessoa jurídica como empresário, avançaram a tese de que o controle seria um bem pertencente à própria companhia, e não a seus acionistas. ${ }^{68}$

Sob essa perspectiva, quem detém o controle tem o poder de influenciar os órgãos administrativos da sociedade. Nas palavras de Guilherme Döring Cunha Pereira, o poder de controle "normalmente não suprime as instâncias decisórias instituídas pela lei ou pelos estatutos. Ao contrário, serve-se dessas instâncias para alcançar as suas finalidades". 69

Há quem defenda que o poder de controle em si é um direito, e a posse desse direito seria plenamente aplicável à realidade societária. ${ }^{70}$ Indaga-se, nesse contexto, se o controle seria então correspondente à simples detenção.

Nos termos da lei civil brasileira ${ }^{71}$, o detentor não possui a coisa em nome próprio, mas sim em cumprimento de ordens de outrem.

Nesse sentido, Comparato consente em admitir que:

"(...) o controle é, pois, o direito de dispor dos bens alheios como um proprietário. Controlar uma empresa significa poder dispor dos bens que lhe são destinados, de tal arte que o controlador se torna senhor de sua atividade econômica". ${ }^{72}$

No mais, não há que se misturar a figura do controlador com o conceito do empresário ${ }^{73}$ do Código Civil, aplicando-se àquele disciplina

\footnotetext{
${ }^{67}$ COMPARATO, Fabio Konder; FILHO, Calixto Salomão. O poder de controle na Sociedade Anônima. 6. ed. Rio de Janeiro: Forense, 2014. p. 91.

68 COMPARATO, op. cit., p. 95-96.

${ }^{69}$ PEREIRA, Guilherme Döring Cunha. Alienação do Poder de Controle Acionário. São Paulo: Saraiva, 1995. p. 11.

${ }^{70}$ COMPARATO, op. cit., p. 103.

71 "Art. 1.198. Considera-se detentor aquele que, achando-se em relação de dependência para com outro, conserva a posse em nome deste e em cumprimento de ordens ou instruções suas."

${ }^{72}$ COMPARATO, op. cit., p. 104.

73 "Art. 966. Considera-se empresário quem exerce profissionalmente atividade econômica organizada para a produção ou a circulação de bens ou de serviços" (grifo nosso).
} 
jurídica própria. No vigente direito societário brasileiro, as funções vinculadas ao acionista controlador podem resumir-se, como bem instrui o artigo 116 da LSA, no poder de orientar e dirigir as atividade sociais. Foi uma escolha do legislador concentrar tais atividades na figura do controlador.

\subsection{Modalidades de alienação de controle}

A forma mais comum de alienação de controle, em nosso país, é a alienação direta do controle, que ocorre quando o acionista controlador, ou grupo vinculado por acordo de acionistas, transfere as ações do bloco de controle que lhe assegura o poder de controle. O controle acionário direto, desse modo, constitui uma modalidade de poder própria da estrutura interna da companhia. ${ }^{74}$

A resolução 401/76 do CMN, no item II, já previa a alienação do controle direto da seguinte forma: "negócio pelo qual o acionista controlador, pessoa física ou jurídica, transfere o poder de controle da companhia mediante venda ou permuta do conjunto das ações de sua propriedade que lhe assegura, de modo permanente, a maioria dos votos nas deliberações da Assembleia Geral e o poder de eleger a maioria dos administradores da companhia".

Diversamente, a lei 10.303/2001, que, como vimos, reintroduziu o artigo da OPA a posteriori na LSA, não exigiu que, para que se torne obrigatória a oferta pública, o controlador venda todas as suas ações nem que todos os integrantes do grupo de controle transfiram o conjunto das suas posições acionárias. Para boa parte da doutrina, a lei previu sabiamente que para a OPA a posterori basta que a operação, em seu conjunto, resulte na alienação do controle da companhia-objeto. ${ }^{75}$

\footnotetext{
${ }^{74}$ CARVAlHOSA, Modesto; EIZIRIK, Nelson. A nova Lei das S.A. São Paulo: Saraiva, 2002. p. 395.

${ }^{75}$ Ibid., p. 397.
} 
Adverte-se que, para os efeitos do atual artigo 254-A, são necessários dois fundamentos para que se caracterize a alienação do controle acionário: (i) que um novo acionista passe a figurar como controlador; e (ii) que a transferência do controle se dê de forma onerosa. ${ }^{76}$

A partir da asserção de que para configurar a OPA a posteriori é imperativa a existência de um novo controlador, decidiu-se pela não realização de oferta pública no Caso Copesul, objeto do Processo CVM RJ 2007/7230, por meio do qual o Colegiado de diretores da referida autarquia entendeu que é requisito para a incidência do artigo 254-A a aquisição do controle por um terceiro estranho à sociedade. ${ }^{77}$

A Copesul era controlada à época, em conjunto, por duas companhias. Quando uma delas adquiriu a totalidade das ações da outra controladora, a operação acarretou a mera consolidação ou concentração de controle nas mãos de quem já era controlador.

No mais, a alienação do controle pode se dar de forma indireta, na medida em que o acionista controlador aliena as ações de companhia controladora da companhia aberta e, como resultado, o controle final desta última. Esse é o controle próprio de um grupo de sociedades, tendo em vista que há uma cadeia hierarquizada composta de duas ou mais sociedades, em que uma comanda o capital da outra. ${ }^{78}$

A transferência do controle indireto será subsidiária à transferência de um controle direto. A título de ilustração: a sociedade A (holding) controla a sociedade B que, por sua vez, controla a sociedade C. A alienação do controle direto de A consequentemente resulta na alienação do controle indireto de $\mathrm{B}$ e C. ${ }^{79}$

Para além dessa questão, o $\S 1^{\circ}$ do artigo 254, da LSA, prevê diversas modalidades de negócios jurídicos que podem caracterizar a OPA

\footnotetext{
${ }^{76}$ CARVAlHOSA, Modesto. Comentários à Lei das Sociedades Anônimas. São Paulo: Saraiva, 2009. v. 4, tomo II, p. 178.

${ }^{77}$ Processo CVM RJ $2007 / 7230$.

${ }^{78}$ EIZIRIK, Nelson. Temas de Direito Societário. São Paulo: Renovar, 2005. p. 240.

${ }^{79}$ PENNA, op. cit., p. 126.
} 
obrigatória, desde que, como vimos (i) resulte na aquisição de controle (ii) de forma onerosa:

"Art. 254-A. A alienação, direta ou indireta, do controle de companhia aberta somente poderá ser contratada sob a condição, suspensiva ou resolutiva, de que $o$ adquirente se obrigue a fazer oferta pública de aquisição das ações com direito a voto de propriedade dos demais acionistas da companhia, de modo a thes assegurar o preço no mínimo igual a $80 \%$ (oitenta por cento) do valor pago por ação com direito a voto, integrante do bloco de controle.

$\S 1^{\circ}$ Entende-se como alienação de controle a transferência, de forma direta ou indireta, de ações integrantes do bloco de controle, de ações vinculadas a acordos de acionistas e de valores mobiliários conversíveis em ações com direito a voto, cessão de direitos de subscrição de ações e de outros títulos ou direitos relativos a valores mobiliários conversiveis em ações que venham a resultar na alienação de controle acionário da sociedade".

Trata-se de um rol não exaustivo de operações que podem ensejar na alienação do controle acionário de uma companhia aberta. Conforme expõe Carvalhosa, "trata-se de um conjunto de exemplos de transações (standards), que podem, por envolverem sempre ações com direito de voto, ou títulos nela conversíveis, resultar na alienação de controle acionário da sociedade". 80

Observe o exemplo dado pelo ilustre autor: o terceiro interessado pode adquirir no mercado um pequeno número de ações, logo, subscreve debêntures conversíveis em ações e, ato contínuo, adquire direitos de subscrições de ações e, mais tarde, compra mais ações, até que adquire uma posição acionária que lhe assegure o poder de controlar a companhia. Note que as etapas não precisam se dar imediatamente, podem se prolongar no tempo, desde que, ao final, resulte na aquisição do controle acionário. ${ }^{81}$

\subsubsection{Aquisição de controle a título originário e a título derivado}

Nos itens antecedentes verificamos que, é indispensável, para aplicação do artigo 254-A, que ocorra alguma transferência de ações que acarrete no surgimento de um novo controlador.

\footnotetext{
${ }^{80}$ CARVAlhoSA, Modesto. Comentários à Lei das Sociedades Anônimas. São Paulo: Saraiva, 2009. v. 4, tomo II, p. 183.

${ }^{81}$ CARVALHOSA, op. cit., p. 184.
} 
Nesaa lógica, a doutrina parte do pressuposto de que um terceiro pode adquirir o controle da companhia-objeto de dois modos: em aquisições a título originário e a título derivado.

Seguindo a própria terminologia, apenas a aquisição derivada do controle, isto é, aquela que ocorre com a transferência onerosa de ações já detidas por um primeiro controlador, dispara o mecanismo do referido artigo.

Partindo desse ponto de vista, Guilherme Döring Cunha Pereira apresenta o conceito de aquisição derivada de controle desta maneira:

"a aquisição derivada pressupõe a preexistência do controle que se vai adquirir. Mas isso só não basta. Quem vai perder o poder deve ter algum papel na transferência, ainda que seja assentindo a ela, pois, do contrario, a hipótese seria de apropriação antes que transferência; aquisição originária, portanto" 82

Em sentido oposto, no caso em que o controle é adquirido sem que o novo controlador tenha comprado as ações do antigo controlador, e sim, por exemplo, quando alguém compra ações suficientes no mercado de modo que lhe assegure o controle, é denominado aquisição originária. ${ }^{83}$

De modo semelhante, também pode constituir aquisição originária do controle quando duas ou mais pessoas celebram um acordo de acionistas, passando a exercer os negócios sociais em conjunto na medida em que estabelecem um bloco de controle, conforme veremos no item a seguir. ${ }^{84}$

Sob essa perspectiva, pode-se determinar que não há transferência de controle que enseje na OPA obrigatória do artigo 254-A, uma vez que a aquisição das ações resulta na formação do patrimônio de um novo controlador, inexistente até então. ${ }^{85}$

Em síntese, só há obrigação de realizar oferta pública de alienação de controle quando estivermos diante de aquisição derivada de controle.

\footnotetext{
${ }^{82}$ PEREIRA, Guilherme Döring Cunha. Alienação do Poder de Controle Acionário. São Paulo: Saraiva, 1995. p. 33.

${ }^{83}$ EIZIRIK, Nelson. Temas de Direito Societário. São Paulo: Renovar, 2005. p. 238.

${ }^{84}$ Ibid, p. 238.

${ }^{85}$ Ibid., p. 239.
} 


\subsubsection{Acordo de Acionistas}

O Acordo de Acionistas é um contrato atípico, ao qual se aplicam os preceito gerais básicos, que deverá ser arquivado na sede da companhia, e com as alterações societárias trazidas pela Lei 10.303/01. O Acordo de Acionistas ganhou uma regulação específica (artigo 118, da $\operatorname{LSA}^{86}$ ).

Como observa Wilson Alberto Zappa Hoog, "o acordo de acionistas é a convenção de acionistas majoritários ou minoritários, para regular a relação entre eles, relativas ao exercício dos direito sociais". ${ }^{87}$ Desse modo, ele pode ser celebrado sobre o exercício do direito de voto, com o objetivo primordial de constituir situação de controle.

Tal situação não seria possível se o controle não fosse compartilhado por um número de acionistas, uma vez que, individualmente, não teriam como impor-se aos demais; portanto, unem-se estabelecendo como se dará a votação do grupo nas assembleias gerais. ${ }^{88}$

\footnotetext{
86 "Art. 118. Os acordos de acionistas, sobre a compra e venda de suas ações, preferência para adquiri-las, exercício do direito a voto, ou do poder de controle, deverão ser observados pela companhia quando arquivados na sua sede. $\S 1^{\circ}$. As obrigações ou ônus decorrentes desses acordos somente serão oponíveis a terceiros, depois de averbados nos livros de registro e nos certificados das ações, se emitidos. $\S 2^{\circ}$. Esses acordos não poderão ser invocados para eximir o acionista de responsabilidade no exercício do direito de voto (artigo 115) ou do poder de controle (artigos 116 e 117). $\S 3^{\circ}$ Nas condições previstas no acordo, os acionistas podem promover a execução específica das obrigações assumidas. $\S 4^{\circ}$ As ações averbadas nos termos deste artigo não poderão ser negociadas em bolsa ou no mercado de balcão. $\$ 5^{\circ}$ No relatório anual, os órgãos da administração da companhia aberta informarão à assembléia-geral as disposições sobre política de reinvestimento de lucros e distribuição de dividendos, constantes de acordos de acionistas arquivados na companhia. $\S 6^{\circ} \mathrm{O}$ acordo de acionistas cujo prazo for fixado em função de termo ou condição resolutiva somente pode ser denunciado segundo suas estipulações. $\$ 7^{\circ} \mathrm{O}$ mandato outorgado nos termos de acordo de acionistas para proferir, em assembléia-geral ou especial, voto contra ou a favor de determinada deliberação, poderá prever prazo superior ao constante do $\S 10$ do art. 126 desta Lei. $\S 8^{\circ} \mathrm{O}$ presidente da assembléia ou do órgão colegiado de deliberação da companhia não computará o voto proferido com infração de acordo de acionistas devidamente arquivado. $\S 9^{\circ} \mathrm{O}$ não comparecimento à assembléia ou às reuniões dos órgãos de administração da companhia, bem como as abstenções de voto de qualquer parte de acordo de acionistas ou de membros do conselho de administração eleitos nos termos de acordo de acionistas, assegura à parte prejudicada o direito de votar com as ações pertencentes ao acionista ausente ou omisso e, no caso de membro do conselho de administração, pelo conselheiro eleito com os votos da parte prejudicada. $\$ 10$ Os acionistas vinculados a acordo de acionistas deverão indicar, no ato de arquivamento, representante para comunicar-se com a companhia, para prestar ou receber informações, quando solicitadas. \$11 A companhia poderá solicitar aos membros do acordo esclarecimento sobre suas cláusulas." (Incluído pela Lei no 10.303, de 2001)

${ }^{87}$ HOOG, Wilson Alberto Zappa. Lei das Sociedades Anônimas comentada. 5. ed. Curitiba: Juruá, 2012.

${ }^{88}$ PEREIRA, Guilherme Döring Cunha. Alienação do Poder de Controle Acionário. São Paulo: Saraiva, 1995. p. 36.
} 
Observe-se que a lei societária, na regulamentação do Acordo de Acionistas, não tratou de dispor qualquer restrição em relação ao exercício do direito de voto. No entanto, a não previsão nesse sentido não se trata de lacuna na lei, mas sim de mero silêncio; silêncio este que o legislador abordou como permissivo. Nessa linha, conclui Waldirio Bulgarelli:

"Os limites, insista-se, ao exercício do direito de voto, através do Acordo de Acionistas, estão basicamente na preservação do interesse social, o que compreende, por óbvio, a não negociação de voto, causa de muitos desencontros no passado.

O modelo legal, como já dissemos, e não custa reiterar, traz consigo seus próprios freios a serem impostos às livres convenções de voto, o que deixa espaço a uma ampla liberdade de orientações por parte dos acionistas conveniados" $"$ (grifo nosso).

\subsubsection{Subscrição de ações}

O poder de controle também pode ser adquirido na hipótese da companhia deliberar um aumento de capital, o qual é totalmente subscrito por apenas um acionista, que não o até então controlador.

Caso essas novas ações, objeto do aumento de capital, sejam em tal quantidade que possibilitem que o subscritor comande a companhia, o exercício do direito de subscrição por este terceiro configurará alienação de controle. $^{90}$

Note que o antigo titular do poder não se retira da sociedade, mas, sim, permanece com uma participação menos significativa no capital da companhia.

Por se tratar de uma alienação de controle um tanto diferente do que viemos estudando até o presente momento, a subscrição de ações num aumento de capital apresenta algumas peculiaridades. Como observa Guilherme Döring Cunha Pereira:

"Ela permite que se opere uma transferência de controle sem a correlata transferência de ações. O valor das ações subscritas, ao contrario do que ocorre na alienação do bloco de ações de controle, será recebido diretamente pela sociedade emissora, beneficiando assim a totalidade do corpo acionário. E se o anterior

\footnotetext{
${ }^{89}$ BULGARELLI, Waldirio. Questões atuais de Direito Empresarial. São Paulo: Malheiros, 2008 p. 196.

${ }_{90}$ PENNA, op. cit., p. 138.
} 
acionista ou grupo controlador tiver recebido pagamento pela desistência de usar de seu direito de preferência, essa remuneração representará integralmente, sem "mistura", o valor do poder de controle".

\subsection{A pulverização de controle no Brasil}

O capital pulverizado ou disperso é aquele detido por vários acionistas individuais, em que não há a figura de um acionista controlador ou grupo de acionistas vinculado por acordo de voto na definição do artigo 116 da LSA. Aqui, não há uma influência permanente nas decisões sociais nem o requisito de permanência, indispensável para a caracterização do controle definido.

Erik Frederico Oioli aponta que uma companhia de capital pulverizado pode ser definida "em função da respectiva forma de poder de controle interno verificado. Quanto maior a dispersão do capital, maior a separação entre propriedade acionária e o poder de controle e, consequentemete, diferente será a forma de configuração do poder de controle". ${ }^{92}$

O requisito de permanência também se fez indispensável em recentes julgamentos pela CVM de casos em que se discutiu a existência ou não do controle. Assim vejamos:

"Outro ponto importante desse primeiro requisito é a necessidade de
permanência do poder. Em razão dele, vencer uma eleição ou preponderar em
uma decisão não é suficiente. É necessário que esse acionista possa,
juridicamente, fazer prevalecer sua vontade sempre que desejar (excluídas,
por óbvio, as votações especiais entre acionistas sem direito a voto ou de
determinada classe ou espécie, ou mesmo a votação em conjunto de açóes
ordinárias e preferenciais, quando o estatuto estabelecer matérias específicas).
Por esse motivo, em uma companhia com ampla dispersão ou que tenha um
acionista, titular de mais de $\mathbf{5 0 \%}$ das ações, que seja omisso nas votações e
orientações da companhia, eventual acionista que consiga preponderar
sempre, não está sujeito aos deveres e responsabilidades do acionista
controlador, uma vez que prepondera por questões fáticas das assembleias não
preenchendo o requisito da alínea "a" do art. 116 , embora preencha o da alínea
"b". Esse acionista seria considerado, para determinação de sua responsabilidade,

\footnotetext{
${ }^{91}$ PEREIRA, Guilherme Döring Cunha. Alienação do Poder de Controle Acionário. São Paulo: Saraiva, 1995. p. 41-42.

${ }^{92}$ OIOLI, Erik, Frederico. Oferta Pública de Aquisição do Controle de Companhias Abertas. São Paulo: Quartier Latin, 2010. p. 34.
} 
como um acionista normal (sujeito, portanto, ao regime do art. 115)",93 (grifo nosso).

A ausência da figura do controlador passa a atrair toda a fiscalização aos administradores da companhia, que começam a comandar de fato a companhia ${ }^{94}$, através do mecanismo denominado proxy machinery, no qual um acionista outorga poderes a terceiro para que este vote em seu lugar. Esse instituto foi, inclusive, recentemente regulamentado pela CVM (instrução CVM 481/2009).

Esse poder dos administradores funda-se no controle gerencial, visto no item 3.2. supra, que, em linhas gerais, entende José Edwaldo Tavares Borba, "será aquele detido por administradores, em face da extrema pulverização do capital, o que lhes permitirá, através da obtenção de procurações, perpetuar-se na direção da sociedade. No Brasil ainda não se configura essa forma de controle, bastante frequente nos Estados Unidos da América"95 (grifo nosso).

Outro fator relevante quanto às companhias de capital pulverizado é a dificuldade de se atingir o quórum necessário em determinadas deliberações em assembleias gerais, como aquelas dispostas no artigo 136 da $\operatorname{LSA}^{96}$, que exige a aprovação de acionistas que representem metade, no mínimo, das ações com direito de voto. Para tanto, a própria lei acionária

\footnotetext{
${ }^{93}$ Processo CVM RJ 2005/4069. Rel. Pedro Oliva Marcilio de Sousa, j. 11.04.2006. Disponível em: <http://www.cvm.gov.br/export/sites/cvm/decisoes/anexos/0002/4788-0.pdf $>$. Acesso em: 30 out. 2015.

$94 \quad$ Disponível em: $\quad$ http://www.conjur.com.br/2006-out14/pulverizacao controle lei_sociedades_anonimas >. Acesso em: 30 out. 2015.

${ }^{95}$ BORBA, José Edwaldo Tavares Borba. Direito Societário. 11. ed. São Paulo: Renovar, 2008. p. 347.

96 “Art. 136. É necessária a aprovação de acionistas que representem metade, no mínimo, das ações com direito a voto, se maior quórum não for exigido pelo estatuto da companhia cujas ações não estejam admitidas à negociação em bolsa ou no mercado de balcão, para deliberação sobre: I criação de ações preferenciais ou aumento de classe de ações preferenciais existentes, sem guardar proporção com as demais classes de ações preferenciais, salvo se já previstos ou autorizados pelo estatuto; II - alteração nas preferências, vantagens e condições de resgate ou amortização de uma ou mais classes de ações preferenciais, ou criação de nova classe mais favorecida; III - redução do dividendo obrigatório; IV - fusão da companhia, ou sua incorporação em outra; V - participação em grupo de sociedades (art. 265); VI - mudança do objeto da companhia; VII - cessação do estado de liquidação da companhia;

VIII - criação de partes beneficiárias; IX - cisão da companhia; X - dissolução da companhia."
} 
indicou uma solução no parágrafo $2^{\circ}$ do referido artigo, em que é permitido à companhia apresentar requerimento à CVM solicitando a redução do quórum qualificado, desde que preenchidos os requisitos contidos no próprio dispositivo, in verbis:

“Art. 136. É necessária a aprovação de acionistas que representem metade, no mínimo, das ações com direito a voto, se maior quórum não for exigido pelo estatuto da companhia cujas ações não estejam admitidas à negociação em bolsa ou no mercado de balcão, para deliberação sobre:

(...)

$\S 2^{\circ}$ A Comissão de Valores Mobiliários pode autorizar a redução do quórum previsto neste artigo no caso de companhia aberta com a propriedade das ações dispersa no mercado, e cujas 3 (três) últimas assembleias tenham sido realizadas com a presença de acionistas representando menos da metade das ações com direito a voto. Neste caso, a autorização da Comissão de Valores Mobiliários será mencionada nos avisos de convocação e a deliberação com quórum reduzido somente poderá ser adotada em terceira convocação" (grifo nosso).

No Brasil, o fenômeno do capital pulverizado surgiu em 2005, quando a J.C.Penney, controladora da varejista Renner, vendeu as suas ações no mercado de bolsa. Além disso, com a obrigatoriedade da existência de apenas ações ON (ordinárias) no Regulamento do Novo Mercado da BM\&BOVESPA, a emissão de novas ações diluiu a participação dos controladores, e, consequentemente, aumentou o número de companhias com capital pulverizado. Atualmente, há cerca de 50 empresas com controle difuso, entre elas a corporation Gafisa, a varejista Hering e a BR Malls, maior empresa de shoppings centers do Brasil. ${ }^{97}$

O conceito de capital disperso pode ser encontrado na lei acionária, em seu artigo 137, II, "b" que considera "dispersão, quando o acionista controlador, a sociedade controladora ou outras sociedades sob seu controle detiverem menos da metade da espécie ou classe de ação".

Por último, importante destacar nesse cenário a possibilidade de um acionista, ou grupo de acionistas, controlar a sociedade sendo detentor de menos da metade do capital social votante da companhia. Isso apenas se

97 Disponível em: <http://www.valor.com.br/valor-investe/o-estrategista/1118274/controledefinido-ou-pulverizado-o-que-e-melhor-para-o-minorita>. Acesso em: 30 out. 2015. 
justifica, no entendimento de Paulo Eduardo Penna quando há uma grande pulverização das ações no mercado de bolsa:

"Há situações, no entanto, em que um acionista (ou grupo de acionistas) consegue controlar a sociedade sendo detentor de menos da metade das ações votantes. Esse fenômeno - que só recentemente começa a ganhar força no Brasil, mas muito comum nos Estado Unidos e na Europa - manifesta-se quando já uma grande pulverização das ações em circulação da companhia, muitas vezes conjugada com um elevado absenteísmo dos acionistas nas assembleias. Nesse cenário, a maioria será apurada pelos acionistas presentes nas assembleias, o que propicia que um acionista (ou grupo de acionistas) titular de um reduzido número de ações consiga, de moro reiterado, fazer prevalecer sua vontade nas deliberações assembleares e eleger a maioria dos administradores. A esse controle, que se funda na titularidade de menos da metade das ações, dá-se o nome de controle minoritário". 98

\subsubsection{Poison pill: mecanismo de defesa nas sociedades de capital pulverizado}

As poison pills ${ }^{99}$ ou pílulas de veneno são um mecanismo de proteção acionária, inserido no estatuto da companhia para garantir a dispersão do seu capital no mercado. ${ }^{100}$

O uso dessa técnica surgiu em 1982, quando Martin Lipton publicou um memorando que consistia em um plano de emissão de opções, com o fim exclusivo de dificultar uma oferta indesejada de aquisição do controle. No ano seguinte, a técnica recebeu o nome de poison pill e até hoje é uma das técnicas mais utilizadas na defesa de aquisições hostis de controle. ${ }^{101}$

Em memorando de entendimentos da CVM datado de 14 de abril de 2008, os diretores Marcos Barbosa Pinto e Otavio Yazbek apresentam três importantes benefícios das poison pills: “(i) elas promovem um tratamento relativamente igualitário entre os acionistas; (ii) elas protegem os acionistas

\footnotetext{
${ }^{98}$ PENNA, op.cit., p. 24.

${ }^{99}$ Definição do Black's Law Dictionary: "A corporation's defense against an unwanted takeover bid whereby shareholders are granted the right to acquire equity or debt securities at a favorable price to increase the bidder's acquisition cost". GARNER, Bryan A. Black's Law Dictionary. $4^{\text {th }}$ Pocket ed. West Group, 2001, verbete poison pill, p. 576.

$100 \quad$ Disponível

em:

$<$ file://Users/laura/Library/Containers/com.apple.mail/Data/Library/Mail\%20Downloads/6B075C 56-3CBC-41BF-B35C670882A5B61A/P\%C3\%ADlulas\%20de\%20veneno\%C2\%A0\%C2\%A0CHR\%20Investor.webarc hive >. Acesso em: 31 out. 2015.

${ }_{101}$ OIOLI, Erik, Frederico. Oferta pública de aquisição do controle de companhias abertas. São Paulo: Quartier Latin, 2010. p. 195.
} 
contra ofertas coercitivas; e (iii) elas aumentam o poder de barganha dos acionistas". 102

Quanto ao tratamento igualitário entre os acionistas, tema discutido na introdução do presente trabalho, Pinto e Yazbek entendem que numa eventual alienação de controle, as poison pills garantem este tratamento igualitário já que estabelecem parâmetros mínimos para fixação do preço da oferta. $^{103}$

No mais, Modesto Carvalhosa explica como essas cláusulas de proteção acionária podem ser inseridas nos estatutos das companhias: "A poison pill estatutária mais utilizada pelas companhias abertas brasileiras consiste em cláusula estabelecendo que a aquisição de determinado percentual de ações de emissão da companhia $(15 \%, 20 \%, 25 \%$...) gera, para o adquirente, o dever de realizar Oferta Pública de Aquisição de ações (OPA) dirigida a todos os demais acionistas". 104

Note-se que a poison pill determina que caso um acionista ultrapasse uma fatia específica do capital total da companhia, este será obrigado a realizar a OPA a posteriori. Assim, fica assegurado aos acionistas que não ocorrerá uma tomada hostil de controle ${ }^{105}$ na sociedade.

No entanto, há quem acredite que as técnicas de defesa não são absolutamente protetivas, já que "elas poderiam servir de instrumento para a perpetuação dos administradores ou acionistas controladores diluídos. Como visto, a OPA representa ameaça ao acionista controlador, quando existente, e aos administradores, que podem ver seus cargos em risco. Há,

\footnotetext{
${ }^{102}$ Disponivel em: <http://www.cvm.gov.br/export/sites/cvm/decisoes/anexos/0005/6491-0.pdf>. Acesso em: 30 out. 2015.

${ }^{103}$ Ibid.

${ }^{104}$ CARVALHOSA, Modesto. As poison pills estatutárias na prática brasileira: alguns aspectos de sua legalidade. In: CASTRO, Rodrigo R. Monteiro; ARAGÃO, Leandro Santos de. Direito Societário: desafios atuais. São Paulo: Quartier Latin, 2009. p. 25.

${ }^{105}$ Tomada hostil de controle ou hostile takeovers "assim definidas as operacōes em que o controle de uma companhia alvo era adquirido por meio de operacōes realizadas no âmbito do mercado, algumas vezes contrariando os interesses do então controlador (obviamente, no caso de controle minoritário) ou dos administradores da companhia (no caso das companhias onde se verificava o controle gerencial)". NETO, Carlos Martins. Dispersão acionária, tomada hostil de controle e poison pills: breve reflexões. Disponível em: <http://www.bocater.com.br/artigos/dispersaoacionaria-tomada-hostil-controle-poison-pills/>. Acesso em: 31 out. 2015.
} 
assim, incentivo para que acionista controlador e administradores ajam na proteção de interesses particulares, usando as técnicas de defesa para amparar suas posições na companhia visada". ${ }^{106}$

${ }^{106}$ OIOLI, Erik, Frederico. Oferta Pública de Aquisição do Controle de Companhias Abertas. São Paulo: Quartier Latin, 2010. p. 200. 


\section{A CVM e a OPA por alienação de controle}

A CVM foi criada pela Lei $n^{\circ} 6.385 / 76$ e consiste em uma autarquia federal vinculada ao Ministério da Fazenda. Esse órgão tem como propósito fiscalizar e regular o mercado de títulos e valores mobiliários e, por isso, seus atos afetam diretamente as companhias abertas e os seus investidores. $^{107}$

Na opinião de Guilherme Döring Cunha Pereira, o legislador, ao criar a CVM, inspirou-se na Securities Exchange Comission (SEC) americana, que foi instituída em 1933 pela lei de emissão pública de títulos societários (Securities Act). ${ }^{108}$

No que tange ao seu papel no instituto da OPA por alienação de controle, a CVM tem duas funções específicas: (i) regulamentar o artigo 254-A da LSA e (ii) autorizar que a companhia realize a OPA por alienação de controle. ${ }^{109}$

A primeira função está prevista no $\$ 3^{\circ}$ do artigo 254-A, in verbis:

"Artigo 254-A. A alienação, direta ou indireta, do controle de companhia aberta somente poderá ser contratada sob a condição, suspensiva ou resolutiva, de que o adquirente se obrigue a fazer oferta pública de aquisição das ações com direito a voto de propriedade dos demais acionistas da companhia, de modo a lhes assegurar o preço no mínimo igual a $80 \%$ (oitenta por cento) do valor pago por ação com direito a voto, integrante do bloco de controle.

$\S 3^{\circ}$ Compete à Comissão de Valores Mobiliários estabelecer normas a serem observadas ma oferta pública de que trata o caput" (grifo nosso).

A função normativa da CVM também está prevista na sua lei de criação $^{110}$ e consiste, basicamente, em estabelecer regras secundárias em complementação às normas legais gerais.

${ }^{107}$ LAMEIRA, Valdir de Jesus. Mercado de capitais. Rio de Janeiro: Forense Universitária, 2001. p. 13.

${ }_{108}$ PEREIRA, Guilherme Döring Cunha. Alienação do Poder de Controle Acionário. São Paulo: Saraiva, 1995. p. 180

${ }_{109}$ PENNA, op. cit., p. 82.

110 "Art . $8^{\circ}$ Compete à Comissão de Valores Mobiliários: I - regulamentar, com observância da política definida pelo Conselho Monetário Nacional, as matérias expressamente previstas nesta Lei e na lei de sociedades por ações; (...)" 
Quanto à OPA por alienação de controle, a CVM exerceu esta atribuição através da Instrução CVM 361/02, a qual não disciplina apenas a OPA do artigo 254-A, mas também a OPA por cancelamento de registro, aumento de participação, voluntária, aquisição de controle e concorrente. Entendimento majoritário da doutrina é no sentido de que a CVM fez bem em reunir, em uma mesma instrução, todas as ofertas públicas relacionadas às companhias abertas, permitindo-lhe estabelecer regras gerais a todas as OPAs e específicas a cada uma delas, de modo organizado e sistemático. ${ }^{111}$

O parágrafo $2^{\circ}$ do artigo $254-\mathrm{A}$ da lei societária atribui à CVM a função de autorizar "a alienação de controle de que trata o caput, desde que verificado que as condições da oferta atendem aos requisitos legais", 112

Essa autorização concedida pela CVM é meramente vinculada. Sobre o tema, esclarece Modesto Carvalhosa e Nelson Eizirik:

"Assim, tal como ocorria no regime anterior, a R. 401/76, o poder da CVM é vinculado não lhe competindo entrar no exame da oportunidade ou da conveniência da alienação de controle, mas meramente verificar se a oferta pública está assegurando aos titulares de ações com direito de voto o pagamento do preço mínimo igual a $80 \%$ do valor pago por ação com direito de voto integrante do bloco de controle". ${ }^{113}$

Observe-se que estando a OPA em conformidade com as exigências da lei, não cabe a CVM entrar no mérito da conveniência e oportunidade da alienação de controle e, portanto, estará obrigada a autorizar a realização da OPA a posteriori. ${ }^{114}$

No mais, interessante lição de Modesto Carvalhosa no sentido de que "a oferta pública constitui uma proposta irrevogável, configurando-se como uma declaração unilateral de vontade obrigatória ao ofertante, nos termos do art. 427 do CC e art. 4, inciso IX, da Instrução CVM n. 361, de 2002.

\footnotetext{
${ }^{111}$ PENNA, 2012, p. 83.

${ }^{113}$ CARVALHOSA, Modesto; EIZIRIK, Nelson. A nova Lei das S.A. São Paulo: Saraiva, 2002. p. 394.

${ }^{114}$ No mesmo sentido, LOBO, Carlos Augusto da Silveira. Alienação de controle de companhia aberta. In: LAMY FILHO, Alfredo; PEDREIRA, José Luiz Bulhões (Coords.). Direito das Companhias. Rio de Janeiro: Forense, 2009. v. 2, p. 2004.
} 
Sendo uma posposta firme e irrevogável, não está a oferta pública de aquisição sujeita a eventuais alterações da vontade de seu autor". ${ }^{115}$

Ademais, no âmbito das OPAs, a CVM tem exercido de modo determinante sua função consultiva. $O$ artigo 13 da Lei $6.385 / 76^{116}$ dispõe que a CVM "manterá serviço para exercer atividade consultiva ou de orientação junto aos agentes de mercado de valores mobiliários ou qualquer investidor".

Assim, agentes do mercado podem promover consultas à CVM de modo que esta manifeste seu entendimento sobre assuntos de sua competência, inclusive se cabe ou não, ao caso a concreto, a realização da OPA por alienação de controle.

Sobre a importância da orientação da CVM na alienação de controle, ensina Paulo Eduardo Penna:

"No âmbito da alienação de controle, as manifestações de entendimento, em especial as decisóes do Colegiado, têm sido um importante instrumento de orientação do mercado a respeito do que caracteriza uma alienação de controle, especialmente diante de determinadas questóes controvertidas. Nesse contexto, as manifestações em geral decorrem de consulta formulada por eventual adquirente do controle, que busca o entendimento da CVM sobre a incidência do art. 254-A da LSA em relação a uma operação específica, ou de reclamação de minoritário quando diverge das condições da OPA ou da sua não realização pelo suposto adquirente do controle". ${ }^{117}$

Ademais, vale destacar que a CVM também possui poder sancionador - estabelecido pela própria Lei $6.385 / 76^{118}$ - isto é, eventual

115 CARVAlHOSA, Modesto. Comentários à Lei das Sociedades Anônimas. São Paulo: Saraiva, 2009. v. 4, tomo II, p. 187.

116 "Art. 13. A Comissão de Valores Mobiliários manterá serviço para exercer atividade consultiva ou de orientação junto aos agentes do mercado de valores mobiliários ou a qualquer investidor.

Parágrafo único. Fica a critério na Comissão de Valores Mobiliários divulgar ou não as respostas às consultas ou aos critérios de orientação."

117 PENNA, op. cit., p. 87.

118 "Art. 11. A Comissão de Valores Mobiliários poderá impor aos infratores das normas desta Lei, da lei de sociedades por ações, das suas resoluções, bem como de outras normas legais cujo cumprimento the incumba fiscalizar as seguintes penalidades: I - advertência; II - multa; III suspensão do exercício do cargo de administrador ou de conselheiro fiscal de companhia aberta, de entidade do sistema de distribuição ou de outras entidades que dependam de autorização ou registro na Comissão de Valores Mobiliários; IV - inabilitação temporária, até o máximo de vinte anos, para o exercício dos cargos referidos no inciso anterior; V - suspensão da autorização ou registro para o exercício das atividades de que trata esta Lei; VI - cassação de autorização ou registro, para o exercício das atividades de que trata esta Lei; VII - proibição temporária, até o máximo de vinte anos, de praticar determinadas atividades ou operações, para os integrantes do sistema de distribuição ou de outras entidades que dependam de autorização ou registro na 
descumprimento de lei ou ato regulamentar, pode ser punido pela própria autarquia.

No âmbito da OPA por alienação de controle, eventuais atrasos na falta de divulgação de ato relevante, ou irregularidades no seu processamento, entre outras violações a leis e atos da CVM, podem vir a causar punições aos agentes de mercado.

Comissão de Valores Mobiliários; VIII - proibição temporária, até o máximo de dez anos, de atuar, direta ou indiretamente, em uma ou mais modalidades de operação no mercado de valores mobiliários; (...)." 


\section{Leading Cases}

Conforme visto durante todo o exposto neste trabalho, com a reintrodução da OPA por alienação do controle em nosso ordenamento, vários problemas que pairavam sobre o tema na vigência do artigo 254 foram solucionados.

No entanto, o mercado imobiliário se desenvolveu e, com isso, os negócios envolvendo transferência de ações precisaram se ajustar à correta compreensão da incidência ou não da OPA por alienação de controle.

Sendo assim, as decisões do Colegiado da CVM têm tido bastante credibilidade no assunto, pois o tema ainda é recentemente novo nos tribunais e, portanto, a jurisprudência é escassa sobre o assunto.

Diante das circunstâncias, a CVM tem sido palco das principais discussões a respeito da OPA a posteriori, principalmente na manifestação de entendimentos sobre reclamações dos minoritários contra a omissão dos acionistas controladores em realizar a OPA. ${ }^{119}$

Vejamos, a seguir, dois casos em que a CVM mostrou-se bemsucedida em seus desfechos, sendo um deles, um dos casos mais intrigantes que teve de lidar, até o presente momento, sobre a OPA por alienação de controle.

\subsection{Caso Coelce}

Trata-se, o referido caso - objeto do Processo CVM RJ 2009/0471de recurso apresentado pelo Fundo Fator Sinergia III - Fundo de Investimento em Ações ("Fundo sinergia") à CVM contra decisão da Superintendência de Registro (SRE), que não caracterizou a alteração do quadro acionário da companhia estrangeira controladora da Companhia Energética do Ceará ("Coelce") como alienação indireta de controle, não

\footnotetext{
${ }^{119}$ PENNA, op. cit., p. 276.
} 
obrigando aos acionistas adquirentes a realizar a OPA do artigo 254-A, LSA.

A Coelce é uma companhia aberta controlada pela Endesa S.A. ("Endesa"), empresa aberta espanhola, que detinha, à época do presente caso, $92 \%$ do capital social votante da organização cearense.

Eis que, no final de 2006, as companhias Acciona S.A. e Enel Engery Europe S.R.L., através de uma OPA de aquisição de controle, passaram a exercer o controle compartilhado da Endesa, empresa esta que, até então, tinha suas ações dispersas no mercado.

O Fundo Sinergia, na qualidade de acionista minoritário da Coelce, requereu que fosse considerado imperioso a realização da OPA do artigo 254-A pelos acionistas da Acciona e da Enel para adquirir as açôes dos minoritários da Coelce, eis que, na sua concepção, o controle da Endesa, antes exercido por um bloco de controle, teria sido transferido à Acciona e à Enel.

Para esses minoritários, o bloco de controle em questão era exercido por um número significativo de acionistas que estavam submetidos a um estatuto social e elegiam administradores e aprovavam determinadas matérias em assembleia em conjunto. Dessa maneira, se enquadravam no conceito de acionista controlador do artigo 116 da LSA.

Na SRE prevaleceu a tese de que a operação não caracterizava alienação de controle para fins do artigo 254-A da LSA, dado que o capital da Endesa encontrava-se pulverizado no mercado e, portanto, não se poderia falar na existência de um acionista controlador que vendeu as ações à Acciona e à Enel. 


\subsubsection{A aquisição originária de controle e a caracterização de um bloco de controle preexistente}

O entendimento da SRE foi mantido pelo diretor relator Otavio Yazbek que votou pela não obrigatoriedade da OPA do artigo 254-A em favor dos minoritários da Coelce.

O argumento do Fundo Sinergia de que havia um controle na Endesa antes da oferta pública de aquisição de ações realizada pela Acciona e Enel, no entendimento de Yazbek, é falho.

Conforme sustentamos no capítulo 2, o acionista controlador do artigo 116, da LSA, deve influenciar os negócios da companhia de maneira permanente, e assim também entendeu o relator ao afirmar que "o art. 116 da Lei $\mathrm{n}^{0} 6.404 / 76$, ao caracterizar a figura do acionista controlador, remete não apenas à capacidade de influenciar, de forma determinante, a tomada de decisões na companhia, mas também a uma consistência temporal no exercício de tal capacidade". ${ }^{120}$

Nesse sentido, Yazbek observou, a nosso ver, corretamente, que não existia um bloco de controle, e sim maiorias eventuais formadas por uma coletividade de acionistas não dotadas do quesito "permanência", indispensável para caracterizar o efetivo exercício do poder de controle de uma sociedade.

Inexistindo um controle, não há que se falar em transferência, e sim na chamada aquisição originária de controle e, portanto, não haveria obrigatoriedade de relação de OPA por alienação de controle. ${ }^{121}$ No mais, conforme discutido no capítulo 3 (item 3.4.1.), só haverá obrigatoriedade de realizar a OPA do artigo 254-A quando estivermos diante de uma aquisição derivada de controle.

\footnotetext{
${ }^{120}$ Processo CVM RJ 2009/0471, rel. Otavio Yazbek, j. 03.03.2009.

${ }^{121}$ No mesmo sentido: Processo CVM RJ n ${ }^{\circ} 2007 / 14099$.
} 


\subsection{Caso Tim Participações}

Versou o caso sobre a obrigatoriedade da realização de OPA a posteriori pela Telco S.p.A ("Telco") para aquisição das ações dos acionistas minoritários da Tim Participações S.A. ("Tim Participações").

JGP Hedge Fundo de Investimento Multimercado, Gávea Brasil Fundo de Investimento Multimercado e outros, acionistas minoritários da Tim Participações, protocolaram requerimento na CVM alegando que o controle da Telecom Italia, controladora indireta da Tim Participações, teria sido transferido de forma onerosa a Telco e, portanto, solicitaram que fosse determinada a realização de OPA, pela Telco, para aquisição das ações de emissão da Tim Participações.

A SRE concordou com a alegação dos Fundos de Investimento e foi a favor da realização da OPA a posteriori pela Telco.

O Colegiado da $\mathrm{CVM}^{122}$, no entanto, após recurso interposto pela Telco, em reunião realizada em 15.07.2009, no Processo CVM RJ 2009/1956, posicionou-se contra a realização da OPA, dando provimento a requisição da Telco.

Contudo, antes de adentrarmos ao mérito do processo, é importante contextualizarmos o caso, dado a sua complexidade. Eis os principais fatos:

(i) a Tim Participações era uma companhia aberta brasileira, titular de empresas de telecomunicações;

(ii) o controle direto da Tim Participações era exercido pela Tim Brasil Serviços e Participações S.A. ("Tim Brasil"), titular de $81,24 \%$ do seu capital votante;

(iii) o capital da Tim Brasil era integralmente detido pela companhia holandesa Telecom Italia Internacional NV que, por sua vez, era subsidiária integral da italiana Telecom Italia S.p.A. ("Telecom Italia");

\footnotetext{
122 Participaram da deliberação Maria Helena dos Santos Fernandes de Santana (Presidente), Eliseu Martins (Relator), Eli Loria, Marcos Barbosa Pinto e Otavio Yazbek.
} 
(iv) a Telecom Italia detinha seu capital pulverizado no mercado, sendo seu maior acionista a Olimpia S.p.A. ("Olimpia"), com participação equivalente a 17,99\%;

(v) a Telco adquiriu $100 \%$ do capital social da Olimpia em 04.04. 2007 e, no mesmo dia, sociedades ligadas a Telco contribuíram para o seu capital social, com 5,6\% de ações da Telecom Italia;

(vi) em síntese, a Telco passou a ter uma participação indireta de $17,99 \%$ no capital da Telecom Italia, através da Olimpia, e uma participação direta de 5,6\%; e

(vii) por fim, em 18.12.2007, a Olimpia foi incorporada pela Telco, a qual passou a ter uma participação direta no capital votante da Telecom Italia de $23,59 \%$.

Diante dos fatos narrados, a alegação dos Fundos de Investimento se pairou sobre a questão de que, para fins de definição de controle, deve-se utilizar a lei de regência da sociedade cujo controle direto foi alterado (por força do artigo 11 da Lei de Introdução ao Código Civil Brasileiro ${ }^{123}$ ).

Assim, aplicando-se a lei italiana, pôde-se chegar à conclusão de que a Olimpia exercia o controle de fato da Telecom Italia e, logo, exercia o controle indireto da Tim Participações. Assim, a alienação do controle direto da Olimpia teria acarretado a alienação do controle indireto da Telecom Italia e, por sua vez, também o da Tim Participações. Dessa maneira, seria obrigatório ao adquirente do controle, no caso a Telco, que realizasse a OPA do artigo 254-A.

Em razão da discussão sobre a lei aplicável para definir controle, a CVM pediu esclarecimentos ao seu equivalente italiano, a Commissione

\footnotetext{
123 "Art. 11. As organizações destinadas a fins de interesse coletivo, como as sociedades e as fundações, obedecem à lei do Estado em que se constituírem. $\S 1^{\circ}$ Não poderão, entretanto, ter no Brasil filiais, agências ou estabelecimentos antes de serem os atos constitutivos aprovados pelo Governo brasileiro, ficando sujeitas à lei brasileira. $\S 2^{\circ}$ Os Governos estrangeiros, bem como as organizações de qualquer natureza, que eles tenham constituído, dirijam ou hajam investido de funções públicas, não poderão adquirir no Brasil bens imóveis ou susceptíveis de desapropriação. $\S 3^{\circ}$ Os Governos estrangeiros podem adquirir a propriedade dos prédios necessários à sede dos representantes diplomáticos ou dos agentes consulares."
} 
Nazionale per le Societá e lá Borsa ("CONSOB"). A CONSOB informou que, para se identificar o controle de fato de uma sociedade, é preciso utilizar diversos critérios. Nesse sentido, para a CONSOB, "a participação necessária para o exercício de influência dominante varia dependendo do nível de dispersão do capital social e do ativismo dos acionistas minoritários, especialmente da sua participação nas assembleias dos acionistas".

Dada a importância de verificar como se realizou o voto dos acionistas nas deliberações assembleares, a CONSOB argumentou que pelo fato de a Olimpia/Telco não ter atingido a maioria dos votos na assembleia de 16.04.2007, poderia se afastar o entendimento de que ela seria controladora da Telecom Italia, já que sua influência se deu sem caráter ocasional.

No entender da SRE, distintamente da CONSOB, é correta a interpretação de que a lei italiana deve ser aplicada para definir se a Olimpia controlava a Telecom Italia. Posicionou-se no sentido de que a OPA deveria ser realizada e afastou-se o argumento de que o fato de a Olimpia/Telco não ter atingido a maioria na Assembleia de 16.04.2007 configuraria um controle meramente ocasional.

Diante da posição adotada pela SRE, a Telco protocolou recurso ao Colegiado da CVM, argumentando, em linhas gerais, que (i) a lei italiana deve ser aplicada para determinar a existência do controle, no entanto, utilizando-se um critério diferente daquele usado pelos Fundos de Investimento, a Olimpia não era controladora da Telecom Italia; e (ii) o artigo 254-A da LSA não pode ser aplicado à alienação de controle minoritário, isto é, quando envolve a transferência de ações de quem detém menos de $50 \%$ do capital votante e, por isso, a OPA não é necessária. 


\subsubsection{Qual a lei aplicável para definir o que é controle e a aplicação do artigo 254-A em alienações de controle minoritário}

O título em questão expõe os dois principais aspectos discutidos pelos membros do Colegiado. Analisaremos, a seguir, os votos apresentados neste intrincado caso.

No entender do Diretor Relator, Eliseu Martins, para a definição do controle, deve-se utilizar a lei brasileira, e não a lei de regência da sociedade cujo controle direto foi alterado.

Além disso, Martins argumentou no sentido de que o artigo 254-A, da LSA, se aplica a transferências de controle tanto minoritário quanto majoritário, assim, o critério de permanência exigido para caracterização do controle não está atrelado a nenhum percentual de ações.

Por fim, concluiu que a Olimpia exercia o controle minoritário da Telecom Itália e votou pelo não provimento ao recurso da Telco, entendendo ser a realização da OPA pela Telco para adquirir as ações dos minoritários da Tim Participações.

Acompanhou o voto do Diretor Relator, o Diretor Marcos Barbosa Pinto. Os outros três membros do Colegiado entenderam pela não configuração de alienação de controle para fins do artigo 254-A. Vejamos quais foram as suas alegações para chegar a tal conclusão.

A Presidente da CVM, Maria Helena Santana, votou no sentido de que a lei italiana deve ser aplicada para definir o controle também com base no artigo 11 da Lei de Introdução ao Código Civil, dando bastante importância a essa questão: "(...) apesar de ser uma questão inicial e que irá delinear a própria análise da transferencia de controle, considero que ela está inserida no âmbito da motivaç̃o do voto como ato administrativo, não sendo uma questão acessória ou preliminar (grifo nosso). Esse entendimento, a Presidente já havia dotado anteriormente no caso Arcelor Brasil $^{124}$.

\footnotetext{
${ }^{124}$ Processo CVM RJ 2006/6209.
} 
A Presidente então passou a examinar a aplicação do artigo 254-A ao caso concreto. Argumentou pela não incidência do referido dispositivo da seguinte forma: uma vez que pela lei italiana não haveria obrigatoriedade de realizar a OPA "seja porque a participacão da Olímpia S.p.A. não poderia ser considerada participação de controle para efeito de gerar a obrigacão de realizacão de OPA naquele país (onde o percentual que pressupõe a existencia de controle foi fixado em $30 \%$ ), seja em razão de a CONSOB não ter julgado possível a caracterizacão do controle de fato exercido pela Olimpia no momento da alienacão ocorrida", também não o seria no Brasil, até porque a lei a ser aplicada, como vimos no parágrafo anterior, é a italiana.

Otavio Yazbek e Eli Loria se manifestaram no sentido de que a lei aplicável ao caso é a legislação brasileira. O primeiro entendeu na mesma linha do Diretor Relator, já Loria se baseou no artigo $9^{\circ}$ da Lei de introdução ao Código Civil ${ }^{125}$.

Note-se que, à exceção da Presidente, o entendimento quase unânime da CVM é no sentido de que a lei aplicável para definir controle é a legislação brasileira.

No que tange o segundo aspecto, Yazbek admitiu que o artigo 254-A pode ser aplicado nas hipóteses de transferência do controle minoritário:

"A maior parte dos possíveis questionamentos, neste ponto, diz respeito à possibilidade de alienacão, para os efeitos do art. 254-A, do poder de controle minoritário ou de fato. $\mathrm{Na}$ verdade, tal possibilidade traria um necessário dilema lógico: como combinar a detenç̃å de uma participação minoritária com aquela detencão, 'de modo permanente', do poder de definir o conteúdo das deliberacōes sociais e de eleger a maioria dos administradores? Trata-se de um dilema - ou melhor, de uma dificuldade - recorrente quando se fala em poder de controle minoritário".

No entanto, votou pela desnecessidade da realização da OPA, pois não conseguiu reunir elementos suficientes que lhe convencessem que a

125 "Art. $9^{\circ}$ Para qualificar e reger as obrigações, aplicar-se-á a lei do país em que se constituírem. $\S 1^{\circ}$ Destinando-se a obrigação a ser executada no Brasil e dependendo de forma essencial, será esta observada, admitidas as peculiaridades da lei estrangeira quanto aos requisitos extrínsecos do ato. $\S 2^{\circ}$ A obrigação resultante do contrato reputa-se constituída no lugar em que residir o proponente." 
incorporação da Olimpia pela Telco fosse the garantir o controle da Telecom Italia e, consequentemente, da Tim Participações.

Importa registrar, por fim, os argumentos utilizados pelo Diretor Eli Loria que o levaram a concluir ser incabível a OPA a posteriori no presente caso: "(...) se o alienante não possui o poder de controle de forma permanente, ainda que seja o controlador de fato, não pode alienar o que não tem e o adquirente se obriga a realizar oferta pública de aquisição perante os demais acionistas. Símile, a qualquer um, no caso ao acionista minoritário, não é permitido exigir aquilo a que não tem direito".

Restou-se, portanto, vencido o voto do Relator no sentido da necessidade da realização da OPA.

Ao nosso ver e reportando-nos aos capítulos e exposições deste trabalho, a alienação do controle da Olimpia enseja na alienação do controle indireto da Tim Participações. Já verificamos que é muito comum que grupos de sociedades sejam estruturados em vários degraus e que, portanto, havendo sociedades controladoras e controladas dentro de determinada cadeia, haverá sempre controle indireto e, como resultado, a transferência onerosa de um desses controles indiretos irá sempre deflagrar a incidência do artigo 254-A da LSA. 


\section{Conclusão}

Durante todo o exposto, pudemos analisar de maneira prática o instituto jurídico da oferta pública por aquisição de ações por alienação do controle acionário - ou tag along -, sem entrar no mérito se o legislador acionário oferece adequada proteção aos acionistas minoritários ou se é justo com os acionistas controladores.

Reportamo-nos ao primeiro capítulo, em que vimos que a finalidade do artigo 254-A da LSA não é meramente a proteção ao acionista minoritário. Há também, por trás desse instituto, a intenção de estimular o mercado de capitais através dos fundamentos advindos com a reforma na legislação de 2001: (i) tratamento equitativo entre os acionistas; e (ii) socialização parcial do prêmio de controle

Verificamos que a OPA por alienação de controle é também denominada OPA obrigatória justamente pelo fato de que, caracterizada a transferência onerosa das ações - ou parte das ações - do titular do controlador da sociedade, é imperioso ao adquirente dessas ações promover o direito aos acionistas minoritários de vender suas ações pelos mesmos termos e condiçôes negociados com o controlador alienante.

Também tivemos oportunidade de analisar como se dá o controle direto e indireto sobre uma companhia. Concluímos que este último é próprio de um grupo de sociedades e que, mesmo que ocorra transferência do controle indireto de uma companhia, se faz também necessária a realização da OPA.

Enfrentamos a problemática dos destinatários da OPA a posteriori que subsiste desde a vigência do artigo 254. Vimos que a instrução CVM 361/02 excluiu a possibilidade do acionista preferencialista com direito de voto restrito ou que tenha adquirido este direito de modo temporário de participar da OPA por alienação de controle. Em contrapartida, concluímos que, na atual redação do instituto na lei acionária, não ha qualquer restrição ao objeto da OPA por alienação de controle. 
Importa registrar que chegamos à conclusão de que, para a ocorrência da alienação do controle necessário, é preciso que (i) um novo acionista passe a figurar como controlador, e (ii) a transferência do controle se dê de forma onerosa. Definimos acionista controlador, por meio da interpretação do artigo 116, LSA, como aquele que detém o poder de comandar uma sociedade, escolhendo seus administradores e definindo, de modo permanente, as linhas básicas de sua atuação.

Tivemos a oportunidade de esclarecer a ambiguidade da expressão "controle da companhia", significando ora "bloco de controle", ora "poder de controle". Concluímos nesta exposição que do bloco de controle nasce o poder de controle. Aquele integra o patrimônio do acionista e este último, diferentemente, se manifesta nas assembleias gerais, por meio do voto.

Importante registrar que verificamos a diferença da aquisição originária de controle da aquisição derivada do controle, concluindo que apenas esta última enseja a OPA do artigo 254-A. Para todos os efeitos, a aquisição originária do controle se dá quando o controle é adquirido sem que o novo controlador tenha comprado as ações do antigo controlador. Ilustramos essa tese através do exemplo de que alguém compra um volume suficiente de ações no mercado de modo que lhe assegure o controle.

Por fim, dedicamos dois capítulos para analisar o papel da CVM na OPA por alienação de controle de maneira teórica e de maneira prática, por meio da análise de dois casos concretos em que a CVM teve de se posicionar a respeito dos institutos da OPA por alienação de controle e da atribuição desses institutos à realidade do mercado acionário.

Nesse sentido, pudemos concluir que a CVM tem duas atribuições importantes: (i) regulamentar o artigo 254-A da LSA, e (ii) autorizar que a companhia realize a OPA por alienação de controle. No mais, a CVM adota um papel importante ao responder consultas de agentes do mercado sobre assuntos de sua competência, principalmente se é obrigatória ou não a realização da OPA por alienação de controle em determinado caso concreto. 
Em suma, pudemos ver tanto no caso Coelce quanto no caso Tim Participações que a CVM adota precedentes para reforçar o seu entendimento sobre determinado aspecto da OPA por alienação de controle.

No mais, verificamos que o fenômeno-objeto deste trabalho é um tema recorrente nos debates sobre Direito Societário e nas discussões envolvendo diversos agentes de mercados. É importante ter o domínio sobre o assunto, principalmente para garantir aos investidores que seus direitos sejam reconhecidos e cumpridos e, consequentemente, que o mercado de capitais seja desenvolvido, propiciando a vários agentes que efetivem negócios jurídicos em que acionistas controladores ou minoritários sejam envolvidos de maneira legítima. 


\section{Referências bibliográficas}

BORBA, José Edwaldo Tavares Borba. Direito Societário. 11. ed. Rio de Janeiro: Renovar, 2008.

BULGARELLI, Waldirio. Questões atuais de Direito Empresarial. São Paulo: Malheiros, 2008.

CARVAlHOSA, Modesto. A nova Lei das Sociedades Anônimas. Rio de Janeiro: Paz e Terra, 1976.

- As poison pills estatutárias na prática brasileira: alguns aspectos de sua legalidade. In: CASTRO, Rodrigo R. Monteiro; ARAGÃO, Leandro Santos de. Direito Societário: Desafios Atuais. São Paulo: Quartier Latin, 2009. p. 25.

. Comentários à Lei das Sociedades Anônimas.

São Paulo: Saraiva, 2009. v. 4, tomo II.

COELHO, Fábio Ulhôa. Curso de Direito Comercial. São Paulo: Saraiva, 2002. v. 2 .

COMPARATO, Fabio Konder. $O$ poder de controle na Sociedade Anônima. São Paulo: Revista dos Tribunais, 1976.

EIZIRIK Nelson; GAAL, Ariadna B.; PARENTE, Flávia; HENRIQUES, Marcus de Freitas. Mercado de capitais - regime jurídico. 2. ed. Rio de Janeiro: Renovar, 2008.

EIZIRIK, Nelson. Oferta pública de aquisição na alienação do controle de companhia aberta. In: Temas de Direito Societário. Rio de Janeiro: Renovar, 2005. 
. Oferta pública de aquisição na alienação do controle de companhia aberta. In: SADDI, Jairo (Org.). Fusões e aquisições: aspectos jurídicos e econômicos. São Paulo: IOB, 2002.

EIZIRIK, Nelson. Temas de Direito Societário. Rio de Janeiro: Renovar: 2005.

GARNER, Bryan A. Black's Law Dictionary. $4^{\text {th }}$ Pocket ed. West Group, 2001, verbete poison pill, p. 576 .

GUERREIRO, José Alexandre Tavares. Alienação de controle de companhia aberta: o papel das instituições financeiras. Revista de Direito Mercantil, Industrial, Econômico e Financeiro, São Paulo, Ed. Revista dos Tribunais, v. 30, 1978.

HOOG, Wilson Alberto Zappa. Lei das Sociedades Anônimas Comentada. 5. ed. Curitiba: Juruá, 2012.

LAMEIRA, Valdir de Jesus. Mercado de capitais. Rio de Janeiro: Forense Universitária, 2001.

LAMY FILHO, Alfredo; PEDREIRA, José Luiz Bulhões. A Lei das S.A. (pressupostos, elaboração, aplicação). Rio de Janeiro: Renovar, 1997. v. 1. LGOW, Carla Wainer Chalréo. Oferta pública obrigatória por ocasião de alienação de controle de companhia aberta (artigo 254-A da Lei das S.A.). Revista Semestral de Direito Empresarial, n. 9, 2011.

LOBO, Carlos Augusto da Silveira. Alienação de controle de companhia aberta. In: LAMY FILHO, Alfredo; PEDREIRA, José Luiz Bulhões (Coords.). Direito das companhias. Rio de Janeiro: Forense, 2009. v. 2.

NETO, Carlos Martins. Dispersão acionária, tomada hostil de controle e poison pills: breve reflexões. Disponível em: 
$<\underline{\text { http://www.bocater.com.br/artigos/dispersao-acionaria-tomada-hostil- }}$ controle-poison-pills/>. Acesso em: 31 out. 2015.

OIOLI, Erik, Frederico. Oferta Pública de Aquisição do Controle de Companhias Abertas. Quartier Latin: São Paulo, 2010.

PARENTE, Norma. Principais inovações introduzidas pela lei $\mathrm{n}^{\circ} 10.303$, de 31 de outubro de 2001, à Lei de Sociedade por Açôes. In: LOBO, Jorge (Coord.). Reforma da Lei das Sociedades Anônimas. Rio de Janeiro: Forense, 2002. p. 40.

PEDREIRA, José Luiz Bulhões. Sistema jurídico da companhia. In: LAMY FILHO, Alfredo; PEDREIRA, José Luiz Bulhões (Coords.). Direito das companhias. Rio de Janeiro: Forense, 2009. v. 1.

PENNA, Paulo Eduardo. Alienação de Controle de Companhia Aberta. São Paulo: Quartier Latin, 2012.

PEREIRA, Guilherme Döring Cunha. Alienação do Poder de Controle Acionário. São Paulo: Saraiva: 1995.

PRADO, Roberta Nioac. Oferta pública de ações obrigatória nas S.A.: "tag along”. São Paulo: Quartier Latin, 2005. p. 43.

Processo CVM RJ 2005/4069. Rel. Pedro Oliva Marcilio de Sousa, j. 11.04.2006. Disponível em: $<$ http://www.cvm.gov.br/export/sites/cvm/decisoes/anexos/0002/47880.pdf>. Acesso em: 30 out. 2015.

SIMIONATO, Frederico Augusto Monte. Considerações sobre tag along e Direito Societário Brasileiro. Revista de Direito Mercantil, Industrial, Econômico e Financeiro, v. 153/154, 2010.

WALD, Alexandre de Mendonça; MORAES, Luiza Rangel. Transferência de controle da companhia aberta. Algumas questões para estudo e reflexão. 
Revista de Direito Bancário e do Mercado de Capitais, São Paulo, Ed. Revista dos Tribunais, n. 38, 2007.

WALD, Arnaldo. O governo das empresas. Revista de Direito Bancário, do Mercado de Capitais e da Arbitragem, São Paulo, Ed. Revista dos Tribunais, n. 15, 2002, p. 68.

\section{Sites}

DEFINIÇÃO DE POISON PILLS. Disponível em: <file://Users/laura/Library/Containers/com.apple.mail/Data/Library/Mail\% 20Downloads/6B075C56-3CBC-41BF-B35C-

670882A5B61A/P\%C3\%ADlulas\%20de\%20veneno\%C2\%A0\%C2\%A0C HR\%20Investor.webarchive>. Acesso em: 31 out. 2015.

PROCESSO DE ALIENAÇÃO DE CONTROLE, N. 2006/7658. Disponível em: $\quad<$ http://www.conjur.com.br/2006-out14/pulverizacao_controle_lei_sociedades_anonimas $>$. Acesso em: 30 out. 2015.

PROCESSO CVM RJ, N. 2006/6209. Disponível em: $<$ http://www.cvm.gov.br/export/sites/cvm/decisoes/anexos/0005/64910.pdf>. Acesso em: 30 out. 2015.

PROCESSO CVM RJ, N. 2005/4069. Disponível em: $<$ http://www.cvm.gov.br/export/sites/cvm/decisoes/anexos/0005/64910.pdf>. Acesso em: 30 out. 2015.

OUTORGA A TERCEIROS POR ACIONISTAS. Disponível em: $<$ http://www.valor.com.br/valor-investe/o-estrategista/1118274/controle- 
definido-ou-pulverizado-o-que-e-melhor-para-o-minorita>. Acesso em: 30 out. 2015.

LISTAGEM NOVO MERCADO DE REGRAS SOCIETÁRIAS. Disponível em: $<$ http://www.bmfbovespa.com.br/pt-br/servicos/solucoes-paraempresas/segmentos-de-listagem/novo-mercado.aspx?idioma=pt-br>. Acesso em: 28 out. 2015. 